\title{
External investigations and disciplinary sanctions against auditors: the impact on audit quality
}

\author{
Cristina De Fuentes ${ }^{1}$ - Manuel Illueca ${ }^{2}$. \\ Maria Consuelo Pucheta-Martinez ${ }^{2}$
}

Received: 8 October 2014 / Accepted: 22 June 2015 / Published online: 15 July 2015 (C) The Author(s) 2015. This article is published with open access at SpringerLink.com

\begin{abstract}
In this paper, we provide empirical evidence for the impact of disciplinary sanctions imposed on Spanish auditing firms and their engagement partners. The disciplinary sanctions resulted from external investigations, which revealed misapplications of auditing standards. In particular, we evaluate (a) the efficacy of the external supervisory board in identifying low-quality auditors and (b) the effectiveness of the disciplinary system in improving the quality of subsequent statutory audits performed by the sanctioned auditors. We employ two earnings management indicators as proxies for audit quality: loss avoidance through extraordinary items and abnormal accruals. And we compare these measures in the financial statements of client companies (auditees) audited by sanctioned and non-sanctioned auditors between 1995 and 2007. Our evidence is mixed. The results show that companies audited by Non-Big 4 sanctioned auditors in the pre-inspection period are less likely to avoid bottom-line losses. Additionally, we conclude that use of this earnings management tool decreases in the post-investigation period for all sanctioned auditors, whether Big 4 or Non-Big 4 firms. Contrary to our expectations, the enhancement performance on this measure of audit quality is observed only for smaller fines. The discretionary accrual approach to earnings management does not offer significant results, however. Therefore, the con-
\end{abstract}

Cristina De Fuentes

cristina.de-fuentes@uv.es

Manuel Illueca

Illueca@cofin.uji.es

Maria Consuelo Pucheta-Martinez pucheta@cofin.uji.es

1 Facultat d'Economía, Universitat de València, Avda. Tarongers s/n, 46021 Valencia, Spain

2 Facultad de Ciencias Jurídicas y Económicas, Universitat Jaume I, Avda de Vicente Sos Baynat, 12071 Castellón de la Plana, Spain 
clusions are not robust, and further investigation is needed. A feasible explanation for the elusive conclusion may be based on the strong incentives for private firms to avoid bottom-line losses for financing purposes and to manipulate earnings to minimize tax payments.

Keywords Auditing - Quality assurance · Audit quality · Oversight - Disciplinary systems · Inspections · Investigations - Sanctions · Earnings management .

Discretionary accruals

\section{JEL Classification $\quad$ M42 $\cdot$ M48}

\section{Introduction}

The aim of this paper is to provide empirical evidence for the effects of the audit investigation and disciplinary system conducted in Spain by Instituto de Contabilidady Auditoría de Cuentas (Institute of Accounting and Auditing, ICAC). More specifically, we explore (a) the efficacy in identifying low quality auditors and (b) the effectiveness in enhancing the quality of subsequent statutory audits of the sanctioned auditors.

The Enron scandal triggered a new auditing market configuration among the big multinational professional services firms. The ensuing Arthur Andersen auditing fiasco reduced the group of international accounting firms from the Big 5 to the Big $4^{1}$ and provided Deloitte and the merged PriceWaterhouseCoopers (PwC) a better placement in the multinational professional services ranking (De Fuentes et al. 2015). The Arthur Andersen debacle resulted in stricter audit regulations in the USA, with the enactment of the 2002 Sarbanes-Oxley Act. Other countries such as France and Canada followed suit (Baker et al. 2014) — as did Spain, where the Financial Act 44/2002 2 included several measures that strengthened the auditor's independence rules. In the European context, it is notable that approval of Directive 2006/43/EC ${ }^{3}$ repealed the former Directive 84/253/EEC. ${ }^{4}$

The common aim of the legislative reforms was the shift from self-regulation of the auditing profession toward a more independent framework (Baker et al. 2014; Gunny and Zhang 2013a). In the USA, the Sarbanes-Oxley Act 2002 (SOX 2002) fostered the creation of the Public Company Accounting Oversight Board (PCAOB). This governmental institution was entrusted with the external review of auditors in order to assess the quality of their services and their compliance with the auditing rules, replacing the

\footnotetext{
1 The Big 5 accounting firms are Deloitte, KPMG, Ernst and Young, PriceWaterhouseCoopers, and Arthur Andersen. The Big 4 excluded Arthur Andersen, after its collapse, in 2002.

2 Ley de Medidas de Reforma del Sistema Financiero 44/2002, de 22 de noviembre. BOE 281 de 23 de noviembre del 2011.

3 Directive 2006/43/EC of the European Parliament and of the Council of 17 May 2006 on statutory audits of annual accounts and consolidated accounts, amending Council Directives 78/660/EEC and 83/349/EEC and repealing Council Directive 84/253/EEC.

4 Eight Council Directive 84/253/EEC of 10 April 1984 based on Article 54 (3) (g) of the Treaty on the approval of persons responsible for carrying out the statutory audits of accounting documents.
} 
traditional peer-review process conducted by and within the auditing firms through the American Institute of Certified Public Accountants (AICPA) program.

In Europe, the quality assurance systems differed among the Member States (García-Osma et al. 2014). With the aim of harmonizing statutory audit requirements, and in the same vein as SOX 2002, Directive 2006/43/EC compelled all Member States to implement a public independent board entrusted with ultimate responsibility for overseeing statutory audits (art. 32 Directive 2006/43/EC). Additionally, Directive 2006/43/EC specified that Member States should ensure that there are effective systems of investigations and dissuasive penalties that would help to detect, correct, and prevent inadequate execution of the statutory audit (art. 30 Directive 2006/43/EC). Overall, the European regulatory reform relies significantly on the independence of the oversight board and its disciplinary system to enhance the quality and credibility of audit services. Therefore, the analysis of the efficacy and effectiveness of this public oversight board is a relevant research issue.

Prior studies, developed mainly in the USA, have largely focused on the comparison between the self-regulated, peer-review system under the AICPA program and the independent supervision system of the PCAOB inspectors. Hilary and Lennox (2005), Gunny and Zhang (2013a), and Anantharaman (2012) conclude that when the auditing firm selects the peer-review supervisor, the outcome of the supervision is less severe than it is under the independent supervision system. The severity is similar only when the peer reviewer is a specialist in the same sector as the supervised auditing firm.

Archival data also illustrates the efficacy of inspections in identifying low-quality auditors. Casterella et al. (2009) show that peer-review reports are aligned with the level of quality offered by US auditing firms. DeFond and Lennox (2011) conclude that low-quality auditors are more likely to receive external reports comprising quality deficiencies than high-quality auditors are. In the same vein, Gunny and Zhang (2013a) show for auditing firms inspected triennially that the disclosure of severe deficiencies in the inspector's report is associated with higher current abnormal accruals in the auditee's financial statements. These auditing firms also exhibit greater propensity to reformulate the annual accounts.

The effectiveness of the quality controls in enhancing audit quality in the USA has been tested by Gramling et al. (2011); they conclude that, within the sample of triennially inspected auditing firms, only those auditors receiving a PCAOB report that included deficiencies modified their outcomes. Carcello et al. (2011) evidence a significant reduction in abnormal accruals in the year following the PCAOB inspections, and these results are stronger for auditees that reported positive abnormal accruals before the quality assessment.

In our view, the literature on the efficacy and effectiveness of the disciplinary system is still limited, calling for further research (see, e.g., DeFond 2010). As most prior research focuses on the outcomes of the supervision of the auditing firm's internal quality control systems (inspections), our work contributes to the archival data by providing empirical evidence on the external supervision of the working papers of a particular audit engagement (investigations). Spain offers an adequate framework for this analysis, because of a tradition, started in the early 1990s, following implementation of the 
Audit Act 1988, ${ }^{5}$ of a quality assurance system based on the investigations-also called technical controls. The independent inspectors report the result of their investigations to the ICAC, which ultimately determines if the auditor has committed an infraction (very serious, serious, or minor), and, if so, the related penalty that would ensue.

The large majority of auditees considered in this study are private, non-listed firms, which belong to the nonfinancial sector and operate in a context of low litigation risk (La Porta et al. 1998) and high alignment between financial and tax accounting (Ball and Shivakumar 2005; Van Tendeloo and Vanstraelen 2008). Therefore, this paper also builds on the extant literature related to the audit quality of the financial statements of small- and medium-sized companies. De Fuentes and Sierra (2015), for example, have documented the impact of regulatory changes in the auditing field over audit quality. Their meta-data demonstrate that SOX 2002 triggered a significantly higher demand for better (more specialized) auditors servicing smaller auditees. In the Spanish context, De las Heras et al. (2012) conclude that Financial Act 44|2002 triggered higher audit quality provided by Big 4 and Non-Big 4 auditing firms, and that financially distressed client companies exhibited greater earnings management constraint. Moreover, this additional effort of the statutory auditor when facing the supervision of a small- or medium-sized auditee with higher business risk is discounted in the fees of the auditing firm (Serrano Madrid et al. 2012). Aguiar-Díaz and DíazDíaz (2015) identify differences in auditor behavior that are linked to client size: Big 4 and Second-Tier firms provide higher audit quality when they audit large client companies, whereas Second-Tier firms provide lower audit quality for their smaller clients. Huguet and Gandía (2014) also demonstrate that those smaller auditees that avoid the audit requirements face higher costs of debt than do client companies that undergo a compulsory audit. Additionally, voluntary audits have no effect on the cost of the debt. Moreover, for family-owned private companies, Corten et al. (2015) suggest that reviews and compilations seem to be sufficient and more cost effective.

In this study we examine the relationship between (a) investigations that identify serious or very serious infractions in the audit process of a particular engagement and b) more generalized misconduct on part of the auditors. We further explore these investigations, asking two related questions: Do they modify the quality of subsequent audits and/or is any change that occurs in auditor's behavior related to the type of penalties imposed.

Our sample consists of annual accounts with the fiscal year included in the period 1995 to 2007, when the application of the new General Accounting Plan ${ }^{6}$ that adapted the International Financial Reporting Standards and triggered major accounting changes (Gonzalo Angulo 2014) took place.

Our study is predicated on the notion that audit quality is not directly observable. As in prior literature (see, e.g., Becker et al. 1998; Francis et al. 1999; Beatty et al. 2002; Krishnan 2003; Arnedo Ajona et al. 2008; Cano 2010; Carmona and Momparler 2011), we explore audit quality differentiation through the auditor's permissiveness toward earnings management-specifically, loss avoidance through extraordinary items and

\footnotetext{
5 Ley 19/1988, de 12 de julio, de Auditoria de Cuentas.

6 Plan General de Contabilidad, approved through RD 1514/2007 of 16 November, 2007.
} 
the discretionary component of accruals in the financial statements supervised by sanctioned and non-sanctioned auditors.

The results stemming from the pre-sanction period show that only clients of NonBig 4 sanctioned auditors exhibit significantly higher likelihood of avoiding reporting negative bottom-line earnings. On the other hand, the evidence provided through the discretionary accrual analysis is weak and inconclusive.

To address our second empirical issue, we restrict the sample to clients of sanctioned auditors and compute our earnings-quality measure before and after the start of the inspections that led to an ex-post sanction. We demonstrate that the earnings management tool-the avoidance of reporting bottom-line losses through extraordinary items - is significantly mitigated in the post-investigation period. Once more, the discretionary accruals approach to audit quality does not offer significant results. We fail to find any difference between the behavior of Big 4 and Non-Big 4 auditors and, contrary to expectations, our data show that Low sanctions seem to be more effective than High sanctions in modifying auditor's behavior.

A feasible explanation for those findings rests on the strong incentives for private auditees to avoid bottom-line losses (Gallén and Giner 2005) when borrowing from banks (Cano 2007), in order to mitigate the negative economic consequences of a deteriorated financial profile. In addition, Spain exhibits a high degree of alignment between financial and tax accounting; therefore private firms face great incentives to manipulate their earnings in order minimize their tax payments (Burgstahler et al. 2006 or Van Tendeloo and Vanstraelen 2008).

The remainder of the paper is structured as follows: Sect. 2 describes the legal and institutional background in which this study is conducted. Section 3 summarizes the literature underpinning the hypotheses we propose to test. The Sect. 4 presents the research design, including an in-depth description of our earnings-quality measures and regression models and the sample and descriptive statistics. Results are reported in Sect. 5, and Sect. 6 presents conclusions.

\section{Institutional background}

\subsection{The legal framework of the external oversight of statutory audits: the Spanish setting within the European context}

Within the European Union, the audit regulatory reforms of the 21 st century followed the path of the Sarbanes-Oxley Act 2002 in the aftermath of the Enron scandal. One of its bases was to move away from the peer-review process of audit quality supervision administered by the AICPA, which had long been criticized for its lack of independence and credibility (see, e.g., Fogarty 1996; Public Overisght Board 2002). The self-regulation framework was replaced in the USA by the independent PCAOB, created under Section 104 of SOX, which conducts inspections of registered public accounting firms that provide audits for publicly traded companies.

García-Osma et al. (2014) have classified the quality assurance systems of the Member States into three categories: a professionally self-regulated system with peerreview (France, Ireland, and the UK), a governmental public oversight system (Finland and Sweden), and a mixed system (Belgium, Germany, and Spain). Consistent with 
the international trend of harmonizing the audit legislation, the Directive 2006/43/EC also backed a more independent supervisory framework. In particular, the European rule required that Member States emphasize that the quality assurance system must be independent of the reviewed statutory auditors and subject to public oversight (art. 26 Directive 2006/43/EC).

In order to enhance the quality of the statutory audits, the transposition of the directive to the legislation of the Member States also accomplishes two processes of supervision: (a) the external supervision of the auditor's internal quality control system or inspections (art. 29 Directive 2006/43/EC) and (b) the external supervision of the working papers of the audit engagements or investigations (art. 30.1 Directive 2006/43/EC). The supervisory function should be complemented with effective and dissuasive sanctions (art. 30.2 Directive 2006/43/EC). More specifically, it states that:

Without prejudice to Member States' civil liability regimes, Member States shall provide for effective, proportionate and dissuasive penalties in respect of statutory auditors and audit firms, where statutory audits are not carried out in conformity with the provisions adopted in the implementation of this Directive (art. 30.2 chap. VII, Directive 2006/43/EC).

All in all, the European legislation requires that all statutory auditors and auditing firms should be submitted to regular inspections conducted by independent bodies and that Member States should implement effective investigation and disciplinary systems that would help to detect and prevent audit malpractice. Despite this regulatory endeavor to harmonize supervisory regimes, the implementation of the public oversight boards across European countries is not homogeneous, and significant differences persist (García-Osma et al. 2014).

In Spain, the twenty-first century brought about deep accounting (a critical review of the process is offered by Gonzalo Angulo 2014) and auditing reforms, but the auditing legislative framework had already embraced an independent supervisory body, the ICAC, from the enactment of the Audit Act in $1988 .^{7}$ Nevertheless, it is remarkable that Spain exhibits a mixed supervisory system (García-Osma et al. 2014), because the ICAC has both the ultimate responsibility for the quality assurance of the statutory audits and for the provision of effective investigation and disciplinary systems (art. 22 Audit Act 19/1988 and in similar terms art 27.3.d Audit Act $1 / 2011^{8}$,) but the Spanish legislation also requires professional associations to oversee the quality of statutory audits (art. 75.f Royal Decree $1990^{9}$ and, in similar terms, art. 65.2 Royal Decree $\left.2011 .^{10}\right)$

\footnotetext{
${ }^{7}$ Ley 19/1988 de 12 de julio de Auditoría de Cuentas.

8 The Audit Act 1988 was amended by the Ley 12/2010 de 30 de junio and repealed by the Real Decreto Legislativo 1/2011 de 1 de julio, por el que se aprueba el Texto Refundido de la Ley de Auditoría de Cuentas (hereafter Audit Act 1/2011), but the date of enforcement of both legislative texts is beyond the temporal scope of our empirical analysis.

9 Real Decreto (1636/1990), de 20 de diciembre, por el que se aprueba el Reglamento que desarrolla la Ley 19/1988, de 12 de Julio, de auditoría de cuenta.

10 The Royal Decree 1990 was repealed by the Real Decreto 1517/2011 de 31 de octubre, por el que se aprueba el Reglamento que desarrolla el Texto Refundido de la Ley de Auditoría de Cuentas 1/2011 de 1 de julio.
} 


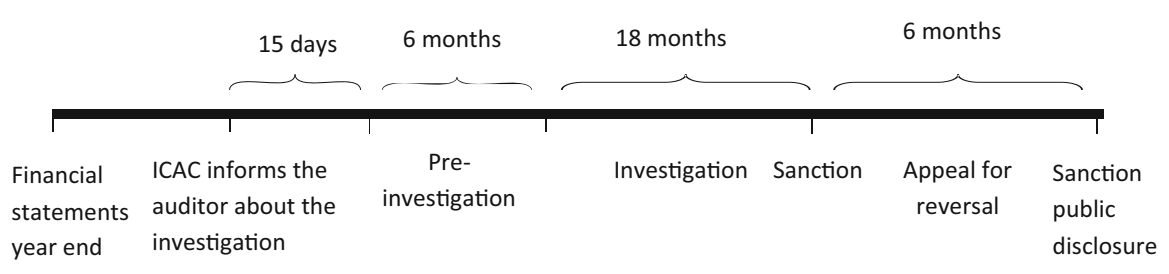

Fig. 1 The average timing of the sanctioning process

Regarding the sanctioning scheme, the Financial Act 44/2002 ${ }^{11}$ and the Audit Act $1 / 2011$ broadened the original two categories of infractions (minor and serious) to include a third-very serious infractions - complemented by the severest penalties. The reforms also resulted in a widening of the circumstances constituting infractions.

\subsection{The investigation process in Spain}

As stated in prior sections, in Spain, the supervisory system embraces the investigations of specific audit engagements through the review of the working papers and the inspections of the internal quality control systems of the auditing firms. Because our analysis focuses on the investigations, we will further explain this type of supervision.

According to auditing legislation, ${ }^{12}$ the initiation of the investigation process by the ICAC inspectors can be made (a) ex-officio, according to an annual plan based on prior evidence provided by the quality controls of the professional associations, analytical procedures, or other objective indicators; or (b) at the behest of any party able to show a legitimate interest. The most common process for starting the investigation was actually the latter, pursuant to a legal claim from a shareholder or another supervisory board (stock market, insurance, or bank authorities, for example). Although less frequent, the investigations also started as a result of the quality controls conducted by the professional associations of the ICAC. ${ }^{13}$

The timing process of ICAC's investigation, depicted in Fig. 1, is of particular relevance in this study. Typically, 15 days before the start date of the technical control, individual auditors or auditing firms are notified by the ICAC that a certain engagement will be subject to investigation. Importantly, the announcement occurs after the corresponding financial statements and its related audit report are placed in the Official Business Register, ${ }^{14}$ so that none of those documents can be modified once the control process is announced. Hence, the auditor's reaction, if any, can be perceived only after the announcement of the inspection.

\footnotetext{
11 Ley de Medidas de Reforma del Sistema Financiero 44/2002, de 22 de noviembre.

12 See art. 28 Audit Act 1/2011 and art. 64 Royal Decree 2011 and, in similar terms, the former art. 22 Audit Act 1988 and art. 65, 66 and 67 Royal Decree 1990.

13 We thank one of the anonymous reviewers for providing details related to the initiation and development of the investigation process.

14 In Spain, all limited liability companies are required to register their financial statements in a local business register.
} 
The whole process encompasses (a) a preliminary investigation process, which normally takes 6 months, conducted after receiving the complaint or detecting the malpractice; (b) the investigation period, which lasts no more than 18 months (art. 30.3. Royal Decree 2011); and (c) the appeal for reversal to the Ministry of Economy, to whom the ICAC belongs, which takes a maximum of 6 months. If the Ministry confirms the decision, the sanction is valid and effective and is published in the ICAC's official bulletin (Boletín del Instituto de Contabilidad y Auditoría de Cuentas, BOICAC), which is publicly available.

Although the infractions can be classified as minor, serious, and very serious (art. 32 Royal Decree 2011), only the last two categories and their penalties are released in the BOICAC. The auditor can appeal in Spain's Administrative Court, however, and this process can take between 1 and 3 years to be resolved.

The sanctions can be either monetary or nonmonetary, including, for the most severe infractions, temporary or even permanent suspension from the Official Register of Auditors (ROAC), which would disallow the auditor to sign statutory audit reports. When the infraction is attributed to an auditing firm, the sanctions are imposed on both the auditing firm and the engagement partner - the partner responsible for the audit, who signs the report.

Regarding the transparency of the oversight process, the ICAC releases an annual report, which includes a summary of the quality controls conducted in the previous year, along with forthcoming work programs (following art. 32 Directive 2006/43/EC). Nonetheless, unlike other regulatory bodies (PCAOB in USA or the Financial Reporting Council in Britain, for instance), the ICAC does not include in its periodical information either the number of or the names of the auditing firms that received clean supervision reports after an inspection or an investigation process, the reason for the initiation of the supervision, or the scope of the investigation process. ${ }^{15}$

The auditor's enforcement releases from 1995 to 2007 are summarized in Table 1. As Panel A reveals, the ICAC official bulletins disclosed 338 infractions, 192 of which correspond to individual auditors and 146 to auditing firms. As depicted in Panel B, the serious infraction which consists of the "non-compliance with auditing standards that could have a significant impact on the outcome of the audit work and, accordingly, on the audit report" is the most common for both the audit firms (130 observations) and individual auditors (166 observations). Regarding the disciplinary actions, Panel $\mathrm{C}$ in Table 1 shows that nonmonetary sanctions, such as a temporary suspension from the Official Register of Auditors, are imposed primarily on individual auditors. By contrast, auditing firms tend to receive heavier monetary sanctions than individual auditors do, because the fines imposed on individual auditors are subject to a cap, which is aimed at capturing the size differences between auditing firms and individual auditors' portfolios.

\footnotetext{
15 As explained in Sect. 2, until 1996 the ICAC used to publish reports with extensive information on the number and the type of detected weaknesses and on the arguments and discrepancies expressed by the sanctioned auditors. The ICAC ceased to publish these reports in 1997, however, in response to pressure exerted by the whole Spanish auditing profession. Since then, only basic or primary information has been disclosed, consisting basically of the names of the auditor and auditee, the type of infraction detected, and the sanction imposed.
} 
Table 1 Auditor's enforcement releases in Spain for the 1995-2007 period

\begin{tabular}{|c|c|c|c|}
\hline & Audit firms & $\begin{array}{l}\text { Individual } \\
\text { auditors }\end{array}$ & \\
\hline \multicolumn{4}{|l|}{ Panel A: Types of infractions } \\
\hline Serious & 146 & 190 & \\
\hline Very serious & 0 & 1 & \\
\hline No information & 0 & 1 & \\
\hline Total & 146 & 192 & \\
\hline \multicolumn{4}{|l|}{ Panel B: Categories of serious infractions } \\
\hline $\begin{array}{l}\text { Non-compliance with the obligation to } \\
\text { perform a mandatory audit in the } \\
\text { course of a firm engagement }\end{array}$ & 0 & 0 & \\
\hline $\begin{array}{l}\text { Issuance of an audit report not based } \\
\text { on the evidence obtained through } \\
\text { the audit procedures }\end{array}$ & 0 & 0 & \\
\hline $\begin{array}{l}\text { Non-compliance with auditing } \\
\text { standards that could have a } \\
\text { significant impact on the outcome of } \\
\text { audit work and, accordingly, on the } \\
\text { audit report }\end{array}$ & 130 & 166 & \\
\hline $\begin{array}{l}\text { Non-compliance with the provisions } \\
\text { regarding auditor independence }\end{array}$ & 13 & 19 & \\
\hline $\begin{array}{l}\text { Failure to report information required } \\
\text { by the Institute of Accounting and } \\
\text { Auditing }\end{array}$ & 2 & 3 & \\
\hline $\begin{array}{l}\text { Acceptance of an engagement } \\
\text { prohibited by law }\end{array}$ & 0 & 1 & \\
\hline $\begin{array}{l}\text { Acceptance of an audit engagement } \\
\text { without being registered in the } \\
\text { Official Register of Auditors }\end{array}$ & 0 & 1 & \\
\hline $\begin{array}{l}\text { Not fulfillment of the requisites for } \\
\text { auditing financial and insurance } \\
\text { firms }\end{array}$ & 1 & 0 & \\
\hline \multirow[t]{3}{*}{ Total } & 146 & 90 & \\
\hline & \multicolumn{2}{|l|}{ Audit firms } & $\begin{array}{l}\text { Individual } \\
\text { auditors }\end{array}$ \\
\hline & Audit firm & Audit partner & \\
\hline
\end{tabular}

Panel C: Sanctions enforced due to serious infractions

Non-monetary sanctions

Public warning

Temporary suspension

0

3

1

Monetary sanctions

Below €6.00000

103

63

117

Above $€ 6.00000$

41

17

Total

146

88

190 


\section{Earnings management in Spanish private companies}

Private companies constitute the majority of the European Union economy and the EU client market for audit services, and Spain is no exception. Therefore, the auditees considered in this study are typically private companies, which, according to the earnings management literature, have a specific set of incentives regarding financial reporting (Ali et al. 2007; Wang 2006; Burgstahler et al. 2006). The capital structure of private companies shows a higher average concentration and managerial ownership than public companies do, and shareholders have access through private channels of information to relevant data on the company's economic performance. Therefore, private client companies arguably face lower agency costs and information asymmetries than stock-market-quoted companies do, but they still have incentives to manipulate earnings because of the conflicts that may arise between controlling and non-controlling shareholders, debt holders, government, and other stakeholders.

In addition, according to La Porta et al. (1998) and Leuz et al. (2003), Spain has weak legal protection for investors and weak enforcement mechanisms, whereby insiders and even large shareholders can enjoy large private control benefits with low litigation risk which leads to more pervasive earnings management (Burgstahler et al. 2006). As a result, the quality of financial reporting could be severely damaged by accounting manipulation practices. More precisely, incentives for earnings management in private companies in Spain arise from three sources. (1) Spain is a bank-oriented economy in which private companies typically hold long-term relationships with banks. Within this relationship-lending environment, banks collect financial information privately rather than via financial statements. Demand for accounting information is lower than in other settings, and earnings quality is therefore lower. (2) Companies face strong incentives to avoid bottom-line losses Gallén and Giner (2005) when borrowing from banks (Cano 2007), in order to mitigate the negative economic consequences of a deteriorated financial profile. The loan loss provisioning system established by the Bank of Spain requires banks to classify loans as non-performing if the borrower exhibits recurrent negative earnings. Because lenders are required to cover up to $25 \%$ of non-performing loans, borrowers face strong incentives to avoid negative earnings in order to reduce the ex-ante cost of debt. (3) As a French legal-origin country, Spain exhibits a high degree of alignment between financial and tax accounting, and tax authorities rely on a company's financial statements to assess taxable income. According to the earnings management literature (Burgstahler et al. 2006 or Van Tendeloo and Vanstraelen 2008), this tight link between accounting numbers and taxable income is expected to boost a company's incentive to manipulate reported profits in order to minimize tax payments.

In summary, the Spanish legal framework contains few control mechanisms to mitigate the earnings manipulation of private companies, and owner-managers face incentives to apply different earnings management strategies in reporting bottomline figures; they are motivated to avoid losses in order to reduce bank-debt associated costs and to minimize profits in order to reduce related income tax payments. 


\section{Hypothesis development}

\subsection{Do disciplinary sanctions identify low-quality auditors?}

Because the ICAC does not disclose information about the results of the quality reviews by the professional associations and the preliminary investigations conducted by the ICAC every year, we do not know the percentage of reviewed engagements that meet the auditing standards. In addition, as stated in Sect. 2, ICAC investigations do not comprise all the engagements of the reviewed auditor. Rather, they involve a specific audit, which is selected according to an ex-ante assessment of audit fraud, because the ICAC's investigation process usually begins only after it receives a legal claim from an interested party (frequently a request from another supervisory body) or the finding of a report of a professional association's audit supervision. It is plausible, therefore, to estimate that most engagement investigations end up with a sanction, but because penalization is associated with a particular engagement, we cannot infer that audit malpractice can be extended to other client audit engagements within that auditing firm's portfolio (DeFond 2010).

In order for disciplinary sanctions to spur an increase in audit quality, then, it is expected that sanctioned auditors must be bad auditors-auditors who engage in generalized auditing misconduct—which, we approach through the permissiveness toward accounting manipulation. Because sanctions are imposed because of a single, specific audit rather than systematic audit malpractice, if penalized auditors are not bad auditors, then changes in auditor's behavior in the post-inspection period are expected to be marginal, regardless of the economic and reputation losses subsequent to the public disclosure of sanctions. In sum, whether or not sanctions are indicative of an auditor's low overall audit quality is an empirical question.

Accordingly, we first determine if sanctioned auditors may be considered bad auditors, particularly if they generally exhibit greater tolerance for higher earnings management practices than non-sanctioned auditors do. In this regard, DeFond and Lennox (2011) report that low-quality auditors are more likely to receive external reports comprising quality deficiencies. Gunny and Zhang (2013a) show that for auditing firms inspected triennially, the disclosure of severe deficiencies in the inspector's report is associated with higher current abnormal accruals in the auditee's financial statements. Low-quality auditors also exhibit greater propensity to reformulate the annual accounts.

Similar to the PCAOB inspection program, we expect the external ICAC investigations to be effective in identifying low-quality auditors. Thus, we expect our empirical evidence to be inconsistent with null Hypothesis 1:

Hypothesis 1 In the pre-inspection period, clients of sanctioned auditors exhibit the same level of earnings quality as do clients of non-sanctioned auditors.

\subsection{Do disciplinary sanctions enhance the penalized auditor's quality?}

Sanctions are expected to trigger a change in auditor's behavior because they entail economic losses steaming from both financial penalties and reputational harm. 
Scholarly contributions on this issue are scarce and inconclusive. Several researchers have tried to determine if the external inspections alone can accomplish a change in audit quality. Carcello et al. (2011) corroborate this hypothesis and have documented a reduction in abnormal accruals resulting from the PCAOB inspection process, and a greater reduction after a second inspection. The evidence is stronger for those auditees that exhibit positive abnormal accruals. The authors conclude that the increase in audit quality is not a temporary phenomenon, but that it lasts after the first inspection and further increases after a second inspection.

Because audit quality is not directly observable by users, the incentive to avoid a negative inspection report may arise from the reputational damage associated with the public disclosure of the infractions (Gunny and Zhang 2013b). Indeed, some US literature (see, e.g., Menon and Williams 1994; Baber et al. 1995; Chaney and Philipich 2002) provides empirical evidence on capital-market effects of auditor reputation loss following high-profile financial scandals.

The literature on the effects of auditor reputation loss following disciplinary actions is relatively limited, however. Public disclosure of audit malpractices and the auditee's intentions to signal a desire for audit quality may precipitate the dismissal of deficient auditors. Auditing firms involved in SEC Accounting and Auditing Enforcement Releases, for example, tend to lose market share relative to their competitors (Wilson and Grimlund 1990) and those receiving clean reports from the peer-review inspectors tend to gain more clients than do firms receiving modified or adverse opinions (Hilary and Lennox 2005). DeFond and Lennox (2011) have demonstrated that audit-market exiting firms are more likely to have received an audit report that included deficiencies and to have avoided quality controls. Gunny and Zhang (2013b) have shown that auditees whose inspected auditors were found GAAP-deficient were more likely to dismiss them in favor of inspected auditors who received a clean report. They also identify PCAOB inspection reports as having created heterogeneity in brand-name reputations among the group usually labeled "Non-Big Auditors". Conversely, Lennox and Pittman (2010) conclude that auditing firms' market shares are insensitive to their PCAOB inspection reports. Moreover, their findings suggest that the auditing market effects of peer-review reports declined after the creation of the PCAOB, because these reports became narrower in scope. In sum, previous literature supports the notion that auditor reputational loss leads to a decrease in client stock returns and a subsequent decline in the market share of auditing firms.

Thus, prior studies provide some, albeit inconclusive, evidence that auditors try to avoid receiving inspectors' reports that disclose deficiencies. This research leads to a related empirical question: Do these fears of receiving a deficient rating from an inspection cause auditors to upgrade their audit methodology and enhance their audit quality? DeFond (2010) supports the idea that PCAOB inspections may improve audit quality if PCAOB inspectors hold the auditors to stricter standards and are able to impose costly penalties. In a sample of triennially inspected auditing firms, only those auditors receiving a PCAOB report including deficiencies tended to modify their outcomes by exhibiting higher likelihood to issuing a going-concern opinion for financially distressed clients in the post-inspection period than they did before being supervised (Gramling et al. 2011). Evidence on auditors who receive a clean inspection report was more limited. In the same vein, Carcello et al. (2011) have demonstrated a 
significant reduction in abnormal accruals in the year following a PCAOB inspection, and these results are stronger for auditees that reported positive abnormal accruals before the inspection.

Because the whole investigation process takes a long time and disciplinary sanctions may significantly damage auditor reputation, auditors face strong incentives to enhance their audit quality at the beginning of the investigation process, either to influence the final outcome of the ICAC or to counteract reputational damage. Hence, we expect our empirical evidence to be inconsistent with null Hypothesis 2:

Hypothesis 2 Clients of sanctioned auditors exhibit the same level of earnings quality in the pre- and post-inspection period.

\section{Research design}

\subsection{Sample selection}

Our sample comprises audited financial statements of nonfinancial companies with a fiscal year end within our 1995-2007 period of study, before the implementation of the New Accounting Plan in 2007. We collected their financial information from the Iberian Balance Sheet Analysis System (Sistemas de Análisis de Balances Ibéricos, $S A B I)$.

After coding the auditors' names, we matched the data on the ICAC inspection reports with the information on Spanish firms included in the SABI database and grouped the financial statements into sanctioned and non-sanctioned auditors. Because there is empirical evidence indicating that audit quality is not homogeneous at a national level for the entire auditing firm - that it may differ across offices (Ferguson et al. 2003; Francis et al. 2005)—we grouped the auditor's clients at a provincial level. Thus a single auditing firm operating in two different provinces is considered as two different auditing firms.

As reported in Panel A of Table 2, the initial database contained 274,291 audited financial statements corresponding to the Spanish nonfinancial firms, but we were able to collect the required information from only 210,273 firm-year observations, which comprises our final sample. Of these, 14,068 firm/year observations refer to the financial statements supervised by a sanctioned auditor either before or after the commencement of the ICAC's investigations. Table 2 reports the total number of firm/year observations, classified by type of auditor (Big 4 vs. Non-Big 4), time (pre- and postinvestigation period), and type of sanction (i.e. High sanctions include nonmonetary penalties and fines higher than $€ 6000$; Low sanctions include fines below $€ 6000$ ).

Endogeneity constitutes a key concern in the relationship between external sanctions and audit quality. Misleading client companies may engage bad auditors to revise their financial statements, so that poor earnings quality may not be caused by low audit quality; but rather bad client companies - for our purposes, earnings managers-with poor earnings quality may choose to hire bad auditors. In this paper, we control for endogeneity in auditor selection by running our models on a subsample of firms with financial statements audited by at least one sanctioned auditor in the pre-inspection period and one non-sanctioned auditor in any year of the sample period. To achieve 
Table 2 Sample selection

Panel A: Overall sample

A Total firm/year observations (1995-2007)

B Financial statements with available information on firm's auditor

C Financial statements supervised by a sanctioned auditor

(i) Big N ( Non Big N)

$10,202(3866)$

(ii) Before (after) the start date of inspections

$3737(10,331)$

(iii) Low (high) Sanction

7838 (6230)

Panel B. Subsample used in the analysis of loss avoidance through extraordinary items: financial statements supervised, at least, by one sanctioned auditor (before the inspection) and one non-sanctioned auditor during the period 1995-1997

A Sanctioned versus non-sanctioned auditors

(i) Initial number of observations with non missing values

(ii) Less number of observations corresponding to firms with all positive or all negative earnings

(iii) Final number of observations used in the loss avoidance tests

B Before versus after the start date of inspections

(i) Initial number of observations with non missing values

(ii) Less number of observations corresponding to firms with all positive or all negative earnings

(iii) Final number of observations used in the loss avoidance tests

Panel C Subsample used in the analysis of discretionary accruals: financial statements supervised, at least, by one sanctioned auditor (before the inspection) and one non-sanctioned auditor during the period 1995-1997

A Sanctioned versus non-sanctioned auditors

(i) Initial number of observations with non missing values

(ii) Less number observations of top and bottom $0.5 \%$ of growth, leverage and Roa

(iii) Final number of observations used in the discretionary accruals tests

B Before versus after the start date of inspections

(i) Initial number of observations with non missing values

(ii) Less number observations of top and bottom $0.5 \%$ of growth, leverage and Roa

(iii) Final number of observations used in the discretionary accruals tests

a clean comparison between the two types of auditors, we remove from the database the financial statements that instigated the ICAC inspection and those supervised by sanctioned auditors in the post-inspection period.

To evaluate empirically the effects of the ICAC disciplinary actions on audit quality, we compute our two proxies for earnings quality in the pre- and post-inspection period, using exclusively the financial statements revised by sanctioned auditors.

In Panels B to C of Table 2, we report the number of observations used in the analysis of loss avoidance and abnormal accruals, respectively. After removing outliers, 
the analysis of loss avoidance through extraordinary items (discretionary accruals) is based on a sample of 2508 (4951) firm-year observations for the comparison between sanctioned and non-sanctioned auditors and $4342(11,261)$ firm-year observations for the comparison between the pre- and post-inspection periods.

\subsection{Descriptive statistics}

Table 3 presents descriptive statistics on a set of performance, solvency, and earningsquality indicators corresponding to the portfolios of sanctioned and non-sanctioned auditors. In particular, descriptive statistics are computed after excluding outliers, which are defined as the observations outside the 0.5 th and 99.5 th percentile of the continuous variables. The empirical evidence included in Table 3 suggests that firms have similar performance and solvency across subsamples. The cash flow to total assets ratio (CFO_ASSETS), the return on assets ratio (Roa) and the net increase in sales (Growth) are approximately 9, 4, and $10 \%$ respectively, whereas the leverage ratio $(L E V)$ is slightly above $60 \%$. The median absolute value of discretionary accruals ( $\left.A B S \_D A\right)$, however, which is higher for the sanctioned auditors' portfolio, reflects higher earnings quality for the firms with financial statements supervised by nonsanctioned auditors.

Table 4 presents the Spearman's correlation coefficients among the variables considered in Table 3. The correlation coefficients between discretionary accruals and leverage, growth, and performance are statistically significant, and their signs are in the direction expected.

\subsection{Measures of earnings quality}

Because audit quality is not observable, in this paper we use two common surrogates of earnings quality: the loss avoidance through extraordinary items and the discretionary component of accruals.

\subsubsection{Loss avoidance through extraordinary items}

As shown in Fig. 2, extraordinary items are widely used by Spanish firms as an earnings management tool. Indeed, $60 \%$ of the firms with slightly negative ordinary income reported positive bottom-line earnings during the period 1995-2007. To evaluate whether this earnings management strategy is associated with ICAC's disciplinary sanctions, we (1) restrict the sample to the client companies that exhibit negative ordinary net income, and (2) test whether the proportion of auditees reporting bottom-line losses depends on the type of auditor. Specifically, to test Hypothesis 1, we check if auditees of sanctioned auditors exhibit the same level of earnings quality (i.e. report ordinary and bottom-line losses), as do auditees of non-sanctioned auditors in the pre-inspection period. Similarly, to test Hypothesis 2, we determine if the clients of sanctioned auditors exhibit the same level of financial information quality (i.e. report ordinary and bottom-line losses) in the pre- and post-investigation periods. 
Table 3 Descriptive statistics

\begin{tabular}{|c|c|c|c|c|c|c|}
\hline Variable & $\mathrm{N}$ & Mean & $\mathrm{SD}$ & 25 th percentile & Median & 75th percentile \\
\hline \multicolumn{7}{|c|}{ Panel A: Variables of sanctioned auditors' clients } \\
\hline Abs_da & 11,171 & 0.100 & 0.100 & 0.030 & 0.069 & 0.136 \\
\hline Loss & 11,921 & 0.180 & 0.384 & 0.000 & 0.000 & 0.000 \\
\hline Ord_loss & 11,921 & 0.198 & 0.398 & 0.000 & 0.000 & 0.000 \\
\hline$\Delta \mathrm{Ni}$ & 11,921 & 0.007 & 0.076 & -0.022 & 0.005 & 0.034 \\
\hline Roa & 11,921 & 0.040 & 0.093 & 0.006 & 0.035 & 0.081 \\
\hline Financing & 11,921 & 0.253 & 0.435 & 0.000 & 0.000 & 1.000 \\
\hline Lev & 11,921 & 0.643 & 0.242 & 0.478 & 0.668 & 0.814 \\
\hline Growth & 11,921 & 0.107 & 0.336 & -0.021 & 0.071 & 0.177 \\
\hline Cfo_assets & 11,921 & 0.094 & 0.193 & -0.001 & 0.088 & 0.194 \\
\hline Lag_Ppe_fin & 11,921 & 0.553 & 0.490 & 0.180 & 0.442 & 0.832 \\
\hline \multicolumn{7}{|c|}{ Panel B: Variables of Non-sanctioned auditors' clients } \\
\hline Abs_da & 166,153 & 0.090 & 0.091 & 0.028 & 0.062 & 0.121 \\
\hline Loss & 172,368 & 0.136 & 0.342 & 0.000 & 0.000 & 0.000 \\
\hline Ord_loss & 172,368 & 0.179 & 0.384 & 0.000 & 0.000 & 0.000 \\
\hline$\Delta \mathrm{Ni}$ & 172,368 & 0.005 & 0.066 & -0.021 & 0.003 & 0.030 \\
\hline Roa & 172,368 & 0.040 & 0.074 & 0.008 & 0.032 & 0.072 \\
\hline Financing & 172,368 & 0.304 & 0.460 & 0.000 & 0.000 & 1.000 \\
\hline Lev & 172,368 & 0.612 & 0.230 & 0.451 & 0.635 & 0.785 \\
\hline Growth & 172,368 & 0.097 & 0.291 & -0.021 & 0.065 & 0.167 \\
\hline Cfo_assets & 172,368 & 0.088 & 0.169 & 0.006 & 0.088 & 0.175 \\
\hline Lag_Ppe_fin & 172,368 & 0.586 & 0.423 & 0.261 & 0.509 & 0.835 \\
\hline
\end{tabular}

Abs_da absolute value of discretionary accruals cross-sectionally estimated using the modified Jones Model, loss 1 if the firm reports losses and 0, otherwise, Ord_loss 1 if the firm discloses negative earnings before extraordinary items and 0 , otherwise, $\Delta \mathrm{Ni}$ change in net operating income over lagged total assets, Roa earnings divided by total assets, Financing 1 if bank debts increase at least $20 \%$ and 0 , otherwise, leverage ratio of total debt to total assets, growth percentage increase in sales, Cfo_assets earnings before extraordinary items - total accruals over lagged total assets, Lag_Ppe_fin lagged value of the ratio of property, plant and equipment plus long term financial assets divided by total assets

Because the set of firms with negative ordinary net income is not randomly selected, the inference drawn from a regular probit model may not extend to the unobserved group. Observations included in the sample are expected to present characteristics that differ from those of the other firms, which may be correlated with either the decision of hiring a non-sanctioned auditor or the changes in auditor behavior in the postinspection period. We therefore estimate a probit selection model (Van de Ven and Van Pragg 1981) consisting of two binary dependent variables: Loss, which equals 1 if the firm exhibits bottom-line losses and 0 otherwise; and OrdLoss, which equals 1 if the firm reports negative ordinary income and 0 otherwise. Because we are interested in analyzing those companies with ordinary losses, in our setting, Loss is observed only if OrdLoss $=1$. Binary outcomes may be expressed using the following set of models: 


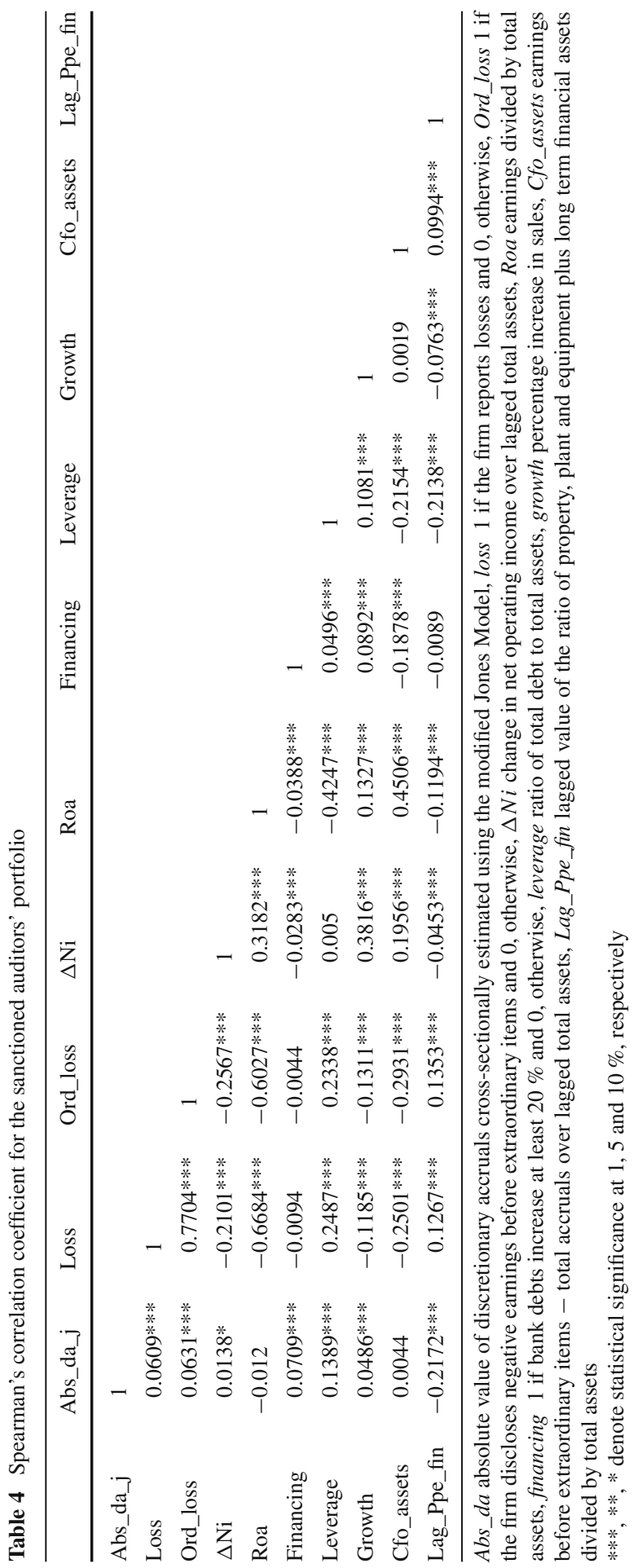




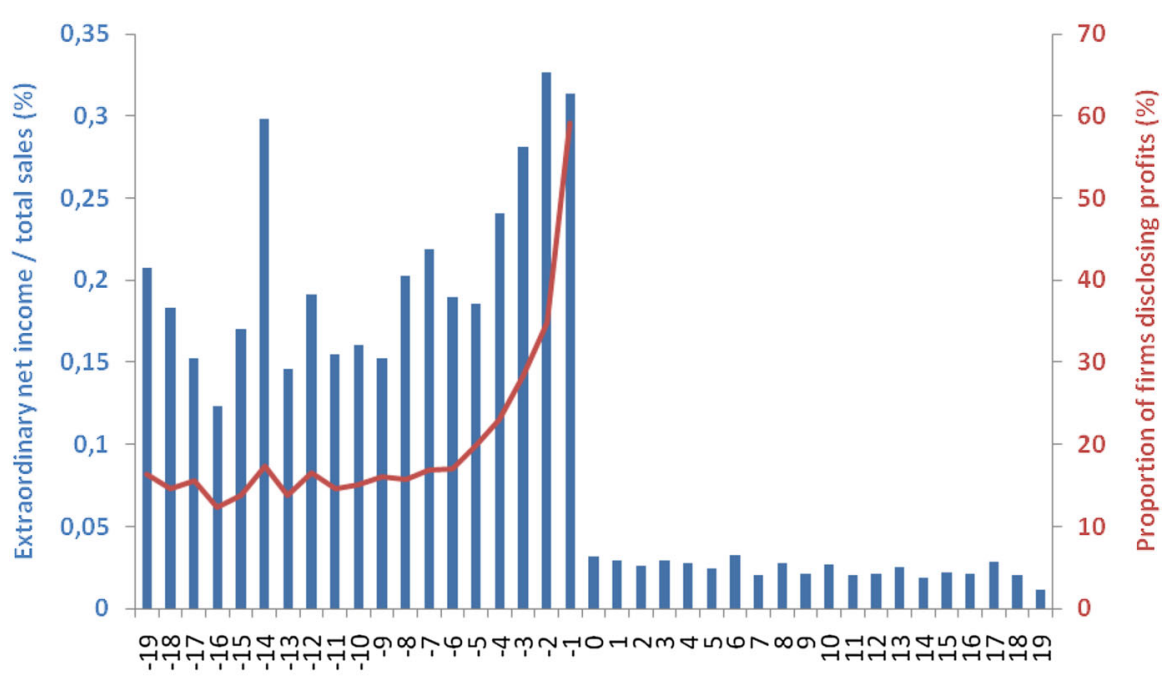

Ordinary net income / total sales (\%)

Fig. 2 Loss avoidance through extraordinary items (1995-2007), the bars refer to the median value of the net income to total assets ratio corresponding to each portfolio of firms. The red line represents the proportion of firms in each portfolio disclosing positive bottom line profits. The minimum and maximum number of firms included in each portfolio is 451 and 30,455 respectively

Model I: Through the equations of the following Model I, we test Hypothesis 1 (i.e. the significance of the sanction over the auditing firm in disclosing bottom-line losses in the pre-investigation period) as:

$$
\begin{aligned}
\text { OrdLoss }_{i t}^{*}= & \beta_{0}+\beta_{1} \text { Cash_flow }_{i t}+\beta_{2} \text { Leverage }_{i t}+\beta_{3} \text { Growth }_{i t} \\
& +\beta_{4} \text { IndOrdLoss }_{i t}+\epsilon_{i t} \\
\text { Loss }_{i t}^{*}= & \alpha_{0}+\alpha_{1} \text { Sanc_Aud }_{i t}+\alpha_{2} \text { LagPpe_fin }_{i t} \\
& +\alpha_{3} \text { IndExtraLos }_{i t}+\varepsilon_{i t}
\end{aligned}
$$

Model II: Similar to Model I, by running the equations of Model II we test Hypothesis 2 to determine if, for those companies audited by sanctioned auditors that report ordinary losses, the period of analysis (pre- and post-sanction) is statistically associated to reporting bottom-line losses:

$$
\begin{aligned}
\text { OrdLoss }_{i t}^{*}= & \beta_{0}+\beta_{1} \text { Cash_flow }_{i t}+\beta_{2} \text { Leverage }_{i t} \\
& +\beta_{3} \text { Growth }_{i t}+\beta_{4} \text { IndOrdLoss } \\
i t & +\epsilon_{i t} \\
\text { Loss }_{i t}^{*}= & \alpha_{0}+\alpha_{1} \text { Event_Sanc }_{i t}+\alpha_{2} \text { LagPpe_fin }_{i t} \\
& +\alpha_{3} \text { IndExtraLoss }_{i t}+\varepsilon_{i t}
\end{aligned}
$$

In Eqs. 1a, 1b, 2a, and 2b, for firm i and fiscal year t:

OrdLoss $=1$ if the firm reports negative ordinary losses in year $t$ and 0 otherwise. 
CashFlow $=$ Cash-Flow/Total assets $_{\mathrm{t}-1}$.

Leverage $=$ Total Debt ${ }_{\mathrm{t}} /$ Total $_{\text {asset }} \mathrm{s}_{\mathrm{t}}$.

Growth $=$ Sales $_{\mathrm{t}}-$ Sales $_{\mathrm{t}-1} /$ Sales $_{\mathrm{t}-1}$.

IndOrdLoss $=$ Firms reporting ordinary losses $/$ Total firms of the firm i industrial sector.

Loss $=1$ if the firm reports bottom-line losses in year $t$, and 0 otherwise.

Sanc_Aud $=1$ if the financial statements were audited by a sanctioned auditor in any year of the pre-sanction period, and 0 otherwise.

Event_Sanc $=1$ if it refers to the pre-sanction period, and 0 otherwise.

LagPpe fin $=\left(\right.$ Property, plant and equipment $\mathrm{t}_{\mathrm{t}}+$ Long-term financial assets $\left._{\mathrm{t}}\right) /$ Total assets $_{\mathrm{t}-1}$.

IndExtraLoss $=$ Firms reporting extraordinary losses $/$ Total firms in the industrial sector of firmi.

Through the logistic regressions in Eqs. $1 \mathrm{~b}$ and $2 \mathrm{~b}$, we estimate the probability of reporting negative net income when the firm also reports ordinary losses, which, under our approach, we identify with higher audit quality. The latent propensity of reporting losses is affected by our two variables of interest (Sanc_Aud and Event_Sanc) and a set of control variables, including Cash flow, Leverage, and Growth. The industrial sector bias is captured by IndOrdLoss and IndExtraLoss, which, in both cases, are computed by using firm-year observations corresponding to firms that never hired a sanctioned auditor during the sample period.

According to our null hypotheses, estimate coefficients of variables Sanc_Aud and Event_Sanc are expected to be negative and positive, respectively.

The estimation of the model relies on the assumption that the error terms $(\epsilon, \varepsilon)$ follow a zero-mean, unit-variance bivariate normal distribution, with corr $(\epsilon, \varepsilon)=$ $p>0$. In this context, estimating the loss equation without considering the effects of the selection equation may lead to biased estimates of the regression coefficients of Eqs. $1 b$ and $2 b$.

\subsubsection{Discretionary accruals}

As a second measure of earnings quality, we conduct an empirical analysis of the nondiscretionary accruals component of earnings. Because the Spanish firms were not obliged to disclose the statement of cash flows during the sample period, we estimate total accruals using the balance sheet approach, similar to that of Arnedo Ajona et al. (2008). Non-discretionary accruals are estimated using the cross-sectional version (Dechow et al. 1995) of the modified Jones (1991) model:

$$
\frac{N D A_{i t}}{T A_{i t-1}}=\alpha+\beta_{0} \frac{1}{T A_{i t-1}}+\beta_{1} \frac{\Delta R E V_{i t}-\Delta A R_{i t}}{T A_{i t-1}}+\beta_{2} \frac{P P E_{i t}}{T A_{i t-1}}+\vartheta_{i t}
$$

Where $N D A_{i t}$ are the non-discretionary accruals; $\triangle R E V_{i t}-\triangle A R_{i t}$ are the sales change net of the variations in account receivables; and $P P E_{i t}$ is net plant, property, and equipment. We deflate by lagged total assets $\left(\mathrm{TA}_{i t-1}\right)$ and, following Kothari et al. (2005), we include an intercept $(\alpha)$ in the estimation to mitigate heteroskedasticity. 
The estimation of the model involves all firm-year observations in the same twodigit industry. To reduce the effect of possible spurious outliers we remove the observations outside the 5th and 95th percentiles of the explanatory and dependent variables. We exclude the industry-year combinations with less than 20 observations. In this paper, we focus on the signed and unsigned residual of the modified Jones Model $\left(S D A_{i t}=\vartheta_{i t}\right.$ and $\left.U D A_{i t}=\left|\vartheta_{i t}\right|\right)$, which, according to previous literature, are assumed to be inversely correlated to earnings quality. ${ }^{16}$

To test our set of hypotheses on the relationship between disciplinary sanctions and earnings quality, we consider the following regression model:

$$
\begin{aligned}
D A_{i t} & =\sum_{j=1}^{J} \alpha_{j} \text { firm }_{j}+\beta_{1} \text { Sanc_aud }_{i t}+\sum_{c=1}^{C} \beta_{c+1} \text { control }_{i t}+\varphi_{i t} \\
D A_{i t} & =\sum_{j=1}^{J} \alpha_{j} \text { firm }_{j}+\beta_{1} \text { Event_Sanc }_{i t}+\sum_{c=1}^{C} \beta_{c+1} \text { control }_{i t}+\varphi_{i t}
\end{aligned}
$$

where the dependent variable $D A$ refers to either unsigned discretionary accruals $(U D A)$ or signed discretionary accruals $(S D A)$; firm is a firm-fixed effect aimed at capturing constant and non-observable characteristics of the firms that are potentially correlated to the dependent variable, and Control refers to a set of control variables, including Roa, the ratio of earnings over total assets; Financing, which is a dummy variable that equals 1 if long-term debts increase at least by $20 \%$ during year $t$ and 0 otherwise; Leverage, which is the ratio of total debt over total assets; Growth, which is defined as the current year growth in sales; and RUDA, which enters the model only in the $U D A$ specification and refers to the ratio of $U D A s$ over total assets in the same year and industry. This ratio is computed by using firm-year observations corresponding to firms that never hired a sanctioned auditor during the sample period. Finally, for our variables of interest, Sanc_aud refers to whether or not the auditor was sanctioned and Event_Sanc refers to the pre- and post-sanction period.

In the UDA specification, we expect the coefficient $\beta_{1}$ to be positive if Sanc_Aud is used as the partitioning variable and negative if Event_Sanc is included in the regression model. Regarding control variables, previous literature suggests the existence of a direct link between firm performance and discretionary accruals. Kothari et al. (2005) include Roa as an additional regressor in the modified Jones model and find it significant, even in a context in which they do not expect the hypothesis of earnings management to hold. With regard to debt, we control for the inception of long-term debt through the variable Financing, which is expected to be positively associated with discretionary accruals, as debtors face incentives to inflate earnings to reduce their perceived riskiness (Ashbaugh et al. 2003). Except for the inception year, we expect an inverse correlation between Leverage and discretionary accruals, because firms are

16 We consider unsigned discretionary accruals (UDA) to evaluate the effect of disciplinary sanctions on both income-decreasing and income-increasing accounting policies. A specific set of control variables is incorporated into models (4a) and (4b) to mitigate the shortcomings of the UDA specification, pointed out by Hribar and Nichols (2007). 
under pressure to report conservatively, so as to build up reserves (Ahmed et al. 2002). Finally, we also expect a positive correlation between discretionary accruals and both RUDA and Growth.

\section{Empirical results}

\subsection{Do sanctions reflect isolated or generalized audit malpractice?}

\subsubsection{Loss avoidance through extraordinary items}

As shown in Fig. 2, when ordinary income is slightly negative, Spanish firms use extraordinary items to avoid bottom-line losses. Non-sanctioned auditors are expected to constrain the manipulation of extraordinary items more than sanctioned auditors are.

In Panels A and B of Table 5 we report the results of the logistic regression models that capture the probability of clients' loss avoidance through extraordinary items. The logit models are run for the whole sample and for different subsamples comprising Big 4 and Non-Big 4 clients.

Data displayed in Table 5, Panel A, show that only clients of Non-Big 4 sanctioned auditors (Sanc_Aud) exhibit significantly higher likelihood of avoiding reporting negative bottom-line earnings ( $p<0.01)$. Regarding control variables, all the coefficients in the selection equation reported in Panel B are significant and their sign is as expected, whereas in the outcome equation the coefficients are not significant at conventional levels.

\subsubsection{Discretionary accruals}

As a second indicator of earnings management, we use both SDAs and UDAs. Panel A of Table 6 reports the difference in average discretionary accruals between firms hiring sanctioned and non-sanctioned auditors. These differences are computed for the whole sample and across subsamples formed according to type of auditor (Big $4 \mathrm{vs.}$ Non-Big 4). The mean of UDA is significantly higher when firms engage a sanctioned auditor ( $p$ value $<0.01$ ). As opposed to the prior loss avoidance result, however, the main differences between the sanctioned and the non-sanctioned auditors' portfolios arise in the Big 4 subsample. Regarding SDAs, the firms hiring a Big 4 sanctioned auditor exhibit significantly lower income-decreasing accruals.

Panel B of Table 6 displays the results of the regression of UDAs on the variable that captures whether or not the auditor was sanctioned (Sanc_Aud) and a set of control variables, including firm-fixed effects. Estimations are conducted for the whole sample and for two other subsamples formed by the clients of Big 4 and Non Big-4 auditing firms. The coefficients are jointly significant in all equations and adjusted $R^{2}$ is approximately $23 \%$. Significance levels of individual coefficients are based on two-tailed $p$ values, which are robust to heteroskedasticity and firm-clustering effects. The variable of interest ( $S a n c_{-} A u d$ ) exhibits only weak significance when the auditor is one of the Big 4 auditing firms. 
Table 5 Loss avoidance through extraordinary items of firms engaging sanctioned and non-sanctioned auditors

Sanctioned vs non-sanctioned auditors

\begin{tabular}{llll}
\cline { 2 - 3 } & All auditors & Type of auditors & \\
\cline { 3 - 4 } Pred sign & Coeff $(\mathrm{z})$ & Big N & Non-Big N \\
Coeff $(\mathrm{z})$
\end{tabular}

Panel A: Probit regression. Dependent variable $=$ Loss

\begin{tabular}{|c|c|c|c|}
\hline Sanc_Aud & $-0.1155(-1.44)$ & $-0.1156(-1.14)$ & $-0.4198 * * *(-2.68)$ \\
\hline Lag_Ppe_fin & $-0.1077(-1.15)$ & $-0.1593(-1.29)$ & $0.1317(0.81)$ \\
\hline IndExtraLoss & $-73.799 * * *(-2.79)$ & $-72.742 * *(-2.34)$ & $-39.077(-0.79)$ \\
\hline Constant & $1.5509 * * *(15.48)$ & $1.8328 * * *(17.70)$ & $0.9478 * * *(4.55)$ \\
\hline$N$ & 5725 & 3217 & 2044 \\
\hline$\chi^{2}$ & $13.6^{* * *}$ & $10.8 * *$ & $8.94 * *$ \\
\hline
\end{tabular}

Panel B: Probit regression. Dependent variable $=$ Ord Loss

$\begin{array}{lllll}\text { Cash Flow } & (-) & -1.8011 * * *(-16.12) & -1.7354 * * *(-12.95) & -1.9610 * * *(-8.90) \\ \text { Leverage } & (+) & 1.3400 * * *(15.12) & 1.3880 * * *(12.47) & 1.2418 * * *(7.97) \\ \text { Growth } & (-) & -0.6800 * * *(-9.93) & -0.5554 * * *(-7.06) & -1.1308 * * *(-7.73) \\ \text { IndOrdLosses } & (+) & 3.1064 * * *(10.29) & 2.4982 * * *(6.30) & 4.1032 * * *(8.33) \\ \text { Constant } & & -2.2267 * * *(-25.17) & -2.0694 * * *(-18.57) & -2.3209 * * *(-15.18) \\ N & & 1059 & 661 & 398 \\ \rho & & -0.5612 * * * & -0.6921 * * * & -0.3630 * *\end{array}$

This table shows the parameter estimates for a probit regression model with sample selection, which may be expressed using the following equations:

$$
\begin{aligned}
\text { Loss }_{i t}^{*} & =\alpha_{0}+\alpha_{1} \text { Sanc_Aud }_{i t}+\alpha_{2} \text { Lag_Ppe_fin }_{i t}+\alpha_{3} \text { IndExtraLoss }_{i t}+\varepsilon_{i t} \\
\text { OrdLoss }_{i t}^{*} & =\beta_{0}+\beta_{1} \text { Cash_flow }_{i t}+\beta_{2} \text { Leverage }_{i t}+\beta_{3} \text { Growt }_{i t}+\beta_{4} \text { IndOrdLoss }_{i t}+\epsilon_{i t}
\end{aligned}
$$

$\operatorname{Loss}_{i t}^{*}$ is the realization of the latent value of the firm's propensity to report bottom-line losses. The firm reports positive bottom-line earnings if $\operatorname{Loss}_{i t}^{*}<0$, and posts losses if $\operatorname{Loss}_{i t}^{*} \geq 0$. The latent propensity of reporting losses is affected by Sanc_Aud and a set of control variables. Lag_Ppe_fin is defined as the lagged ratio of property, plant and equipment plus long term financial assets over total assets and IndExtraLoss refers to the median value of the ratio of extraordinary net income over total assets in year $t$ and in the same industry as firm $i$. OrdLoss $s_{i t}^{*}$ realization of the latent value of the firm's propensity to exhibit negative ordinary losses in year $t$. The firm reports ordinary losses if $\mathrm{OrdLoss} \mathrm{L}_{i t}^{*} \geq 0$ and ordinary positive earnings if $\mathrm{OrdLoss}_{i t}^{*}<0$. Latent propensity is explained by a set of control variables, Cash Flow ratio of cash flow to total lagged assets, Leverage ratio of total debt to total assets, Growth percentage increase in sales, IndOrdLoss $s_{i t}$ ratio of firms reporting ordinary losses to total firms in year $t$ and the same industry as firm $i$. To control for endogeneity in auditor's selection, the model is estimated using a restricted sample of firms, which hired, at least, one sanctioned auditor in the pre-inspection period and one non-sanctioned auditor in any year of the sample period. $\rho$ estimated correlation coefficient of both error terms. $Z$-statistics are robust to heteroscedasticity $* * *, * *, *$ denote statistical significance at 1,5 and $10 \%$, respectively 


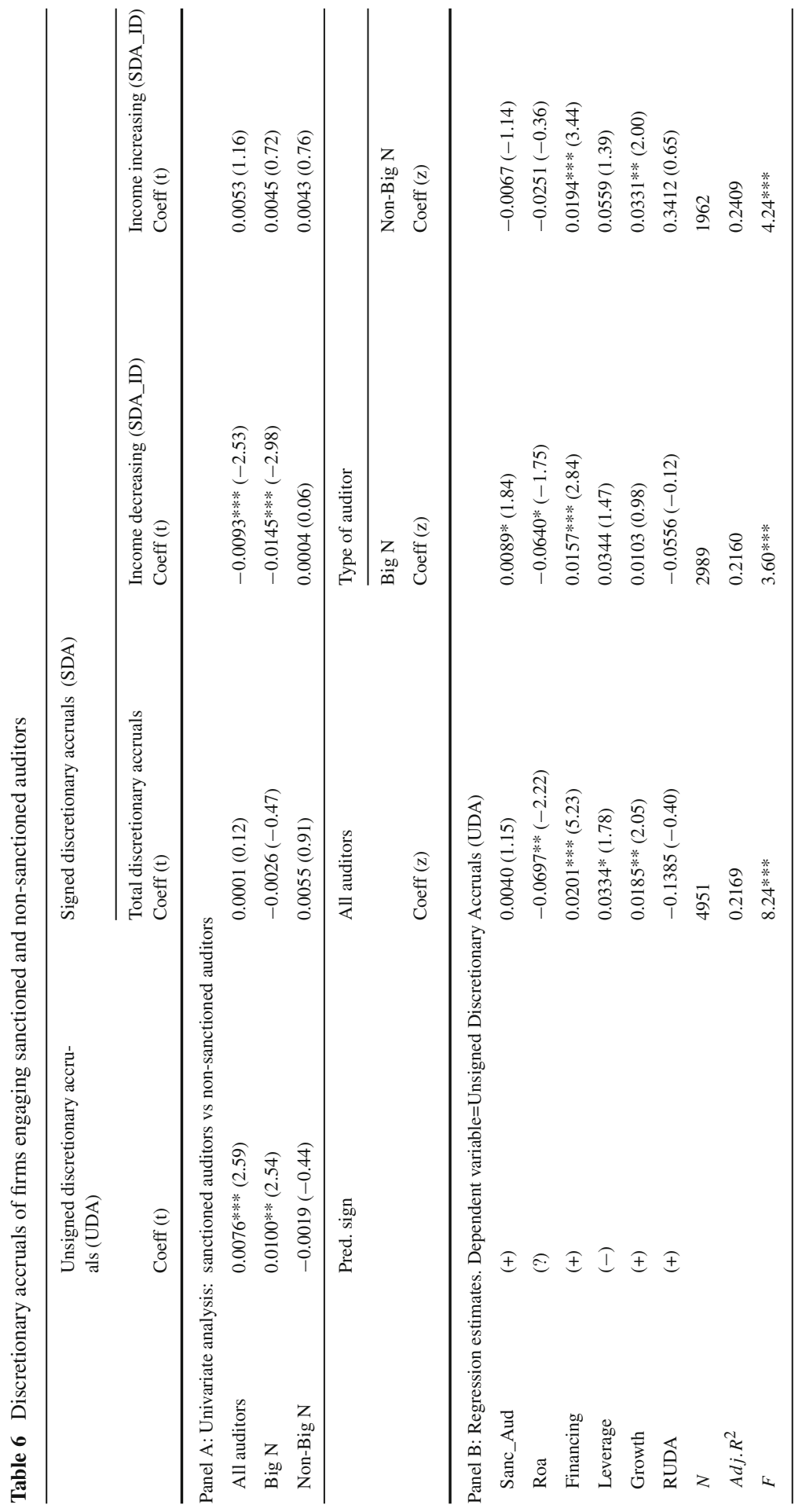




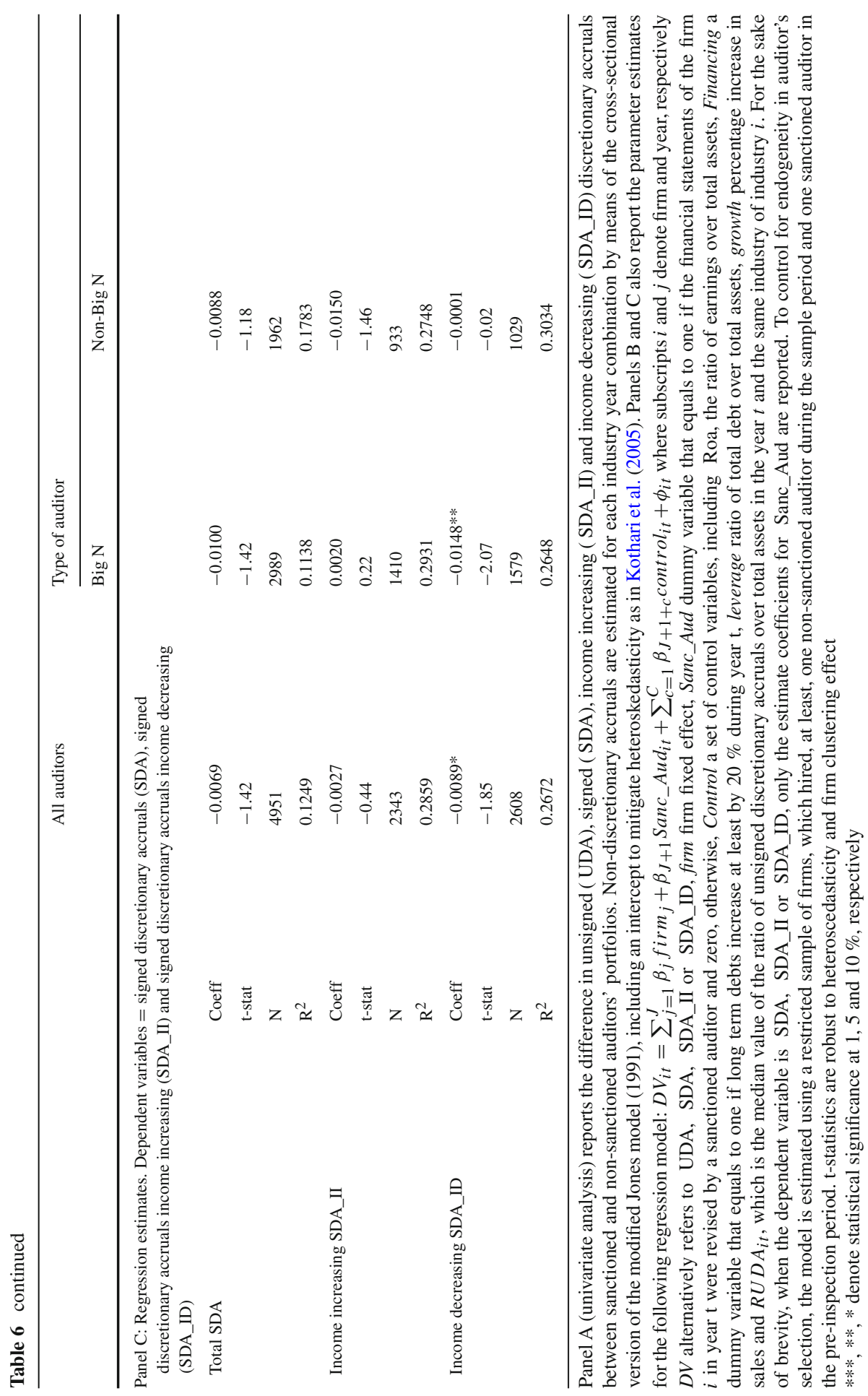


In addition, Panel $\mathrm{C}$ of Table 6 exhibits the results of the regression of signed discretionary accruals, both income-increasing (SDA_II) and income-decreasing accruals (SDA_ID), on the variable that captures the sanction of the auditor (Sanc_Aud). The results show that the variable of interest is significant only at the $1 \%$ level in the incomedecreasing specification for the Big 4 subsample, with a negative sign suggesting that clients of Big 4 sanctioned auditors disclose significantly lower discretionary accruals only when engaging in conservative accounting policies.

In sum, the analysis of discretionary accruals leads to inconclusive results regarding Hypothesis 1. According to univariate tests, UDAs are higher when firms engage a sanctioned auditor. The effect of disciplinary sanctions vanishes, however, when a regression analysis is considered. Non-Big 4 sanctioned auditors do not manipulate accruals, whereas Big 4 auditors seem to specialize in accruals manipulation to deflate earnings.

\subsection{Does audit quality increase after the investigation?}

This section provides an empirical evaluation of Hypothesis 2, which focuses on the efficacy of ICAC sanctions in improvement of audit quality. The sample is restricted to the financial statements supervised by sanctioned auditors, either before or after the start date of the disciplinary process. Earnings quality is expected to increase in the post-inspection period, compared to the pre-inspection period. The results of our empirical analysis are reported in Tables 7 and 8.

\subsubsection{Loss avoidance through extraordinary items}

Panels A and B in Table 7 summarize the results concerning our analysis of loss avoidance when applying a conditional logistic regression, in which the dichotomous output Loss depends on the partitioning variable, Sanc_Event, which captures the preand post-sanction period and a set of control variables, including firm fixed effects. The coefficient of variable Sanc_Event is positive and statistically significant for the whole sample. This result suggests that in the post-inspection period, audited financial statements exhibit a lower tendency to avoid bottom-line losses through extraordinary items. When the sample is split into Big 4 and Non-Big 4 auditing firms, the coefficient remains positive, although not statistically significant. Regarding the severity of the sanction (Low and High), the parameter estimate for the variable Sanc_Event presents a positive sign and is statistically significant for Low sanctions. Therefore, this finding suggests, given that audited financial statements show a lower tendency to avoid bottom-line losses through extraordinary items, that companies audited by an auditor who has received a low sanction, enhance financial reporting quality in the post-inspection period.

\subsubsection{Discretionary accruals}

Table 8 shows the effects of the ICAC's inspections on the discretionary accruals reported by clients of sanctioned auditors. Hypothesis 2 is tested considering SDAs and 


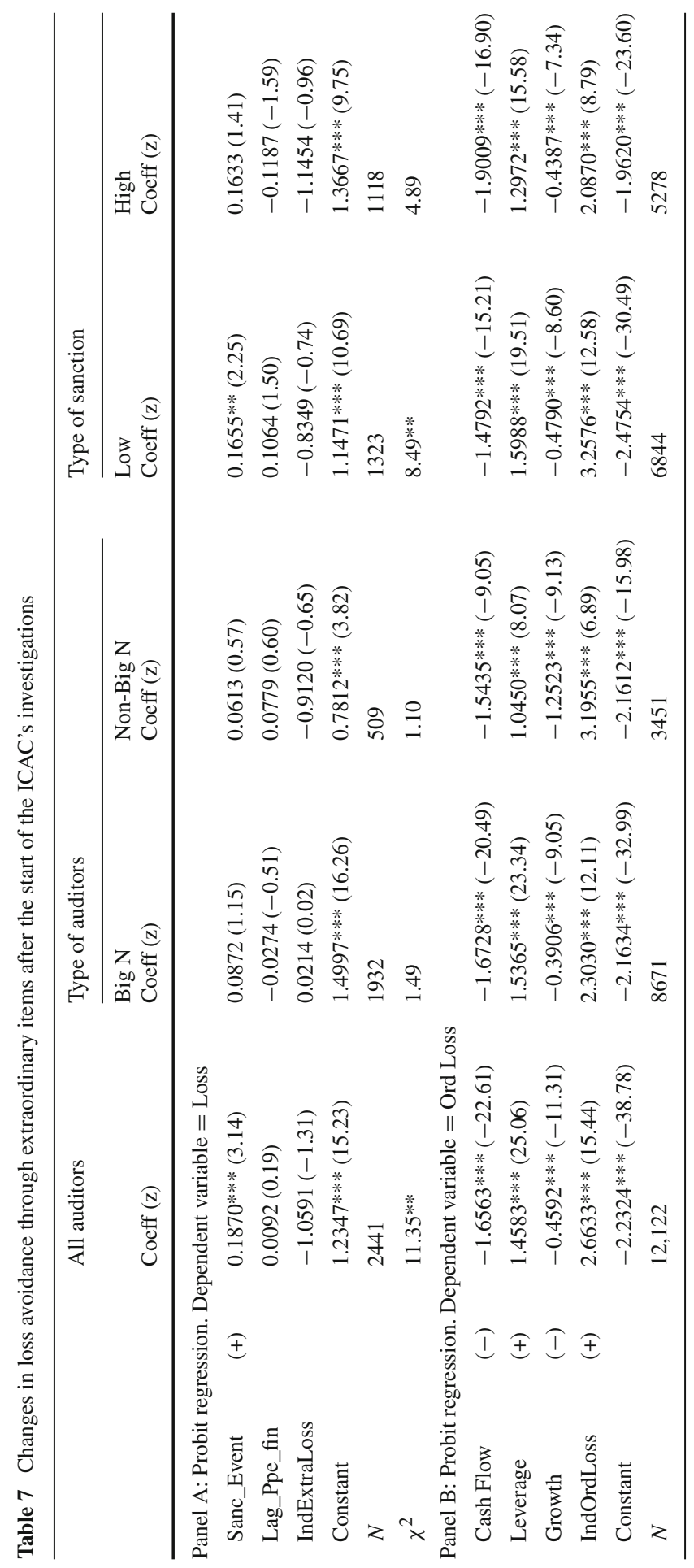




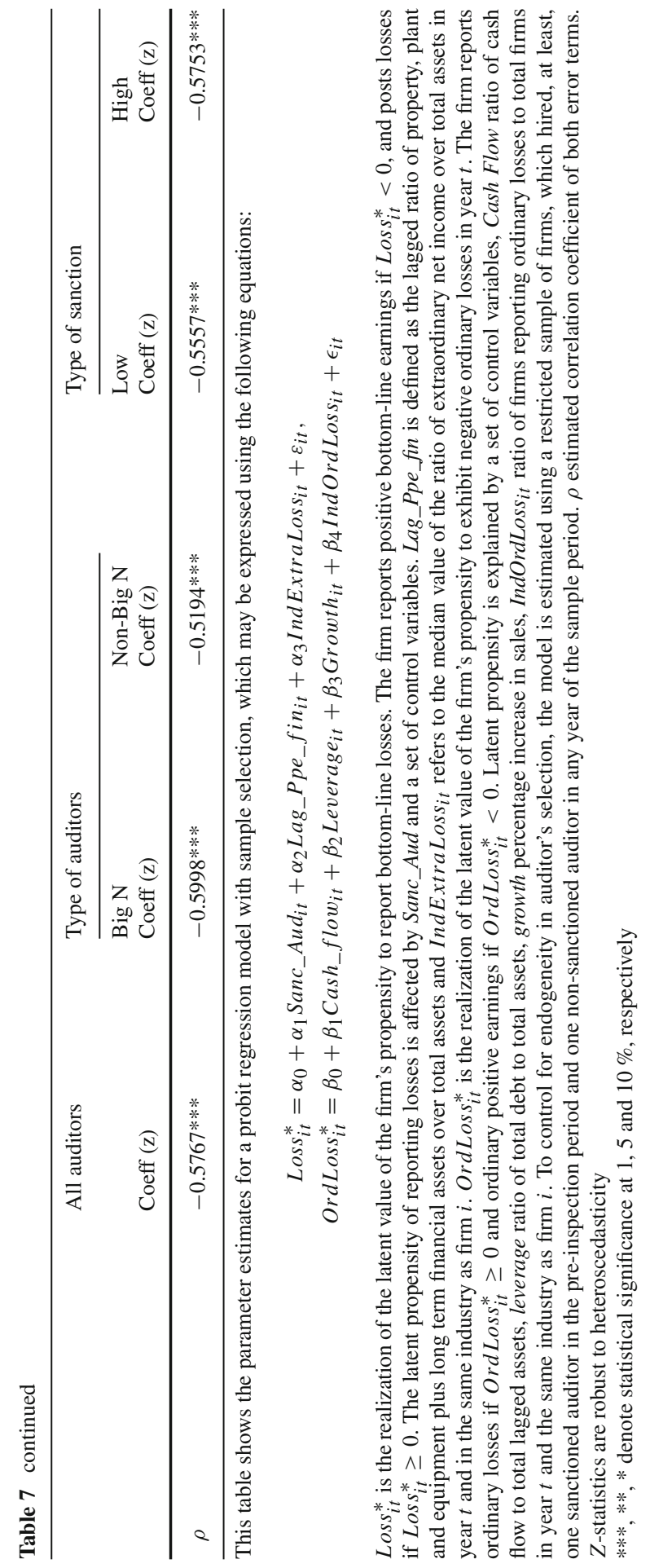


UDAs. In turn, SDAs are broken down into income-increasing (II_SDA) and incomedecreasing (ID_SDA) accruals, because auditor's reaction to ICAC's inspections may depend on the nature of the accounting policies established by the firm.

Univariate tests show that discretionary accruals significantly decrease after the commencement of ICAC's inspections, although not uniformly across different types of auditors. Consistent with the empirical evidence reported in the previous section, only clients of Big 4 auditors exhibit significantly lower discretionary accruals in the post-inspection period. In the Big 4 auditor's client subsample, UDAs and SDAs decrease by 1.3 and $0.8 \%$ of total assets, respectively ( $p$ values $<0.05$ ). As expected, auditor's reaction is stronger when inspections end up assessing a fine above $€ 6000$ or a nonmonetary sanction. When inspections lead to a fine of less than $€ 6000$, auditors restrict only income-increasing accruals. By contrast, when a more severe sanction is imposed by the ICAC, auditors' reactions involve both income-increasing and incomedecreasing accruals.

As mentioned, higher earnings quality in the post-inspection period does not necessarily entail an increase in audit quality. Big 4 auditors may engage in better client selection after the commencement of ICAC's inspections. To control for this possibility, we regress our different measures of accrual management on the partitioning variable Sanc_Event and a set of control variables, including firm-fixed effects. Under the assumption that audit quality actually increases after the beginning of the disciplinary process, we expect lower accruals manipulation by pre-existing clients, and, therefore, the coefficient of Sanc_Event should be negative and statistically significant. As is readily apparent from Panels $\mathrm{B}$ and $\mathrm{C}$ of Table 8, neither in UDA nor in the $S D A$ specification is the coefficient significant for subsample of Big 4 clients, suggesting that the decrease in abnormal accruals observed in the Big 4-sanctioned auditors' portfolio is associated with client selection rather than with better audit quality.

\subsection{Robustness tests: regions and firm size}

To test the robustness of our results, we conducted two sensitivity analyses by partitioning the sample according to two criteria: region and firm size. With regard to regions, one could argue that earnings quality varies across Spanish provinces depending on their degree of economic and financial development (Monterrey and Sánchez-Segura 2006). Accordingly, we empirically test Hypotheses 1 and 2 using two subsamples of firms operating in and out of Madrid. Our results remain qualitatively unchanged in both subsamples after controlling for the different market share of Big 4 and Non-Big 4 auditors in Madrid and the rest of Spain. ${ }^{17}$

Our second sensitivity analysis deals with the relationship between earnings quality and firm size. Because the future cash flows of small companies are less predictable than those of big companies (Dechow and Dichev 2002), earnings quality is expected to be positively related to client company size. In addition, big clients are expected to increase disclosure quality because they face increased demand for accounting quality

\footnotetext{
17 For the sake of brevity, we do not report these results; however, they are available from the authors upon request.
} 


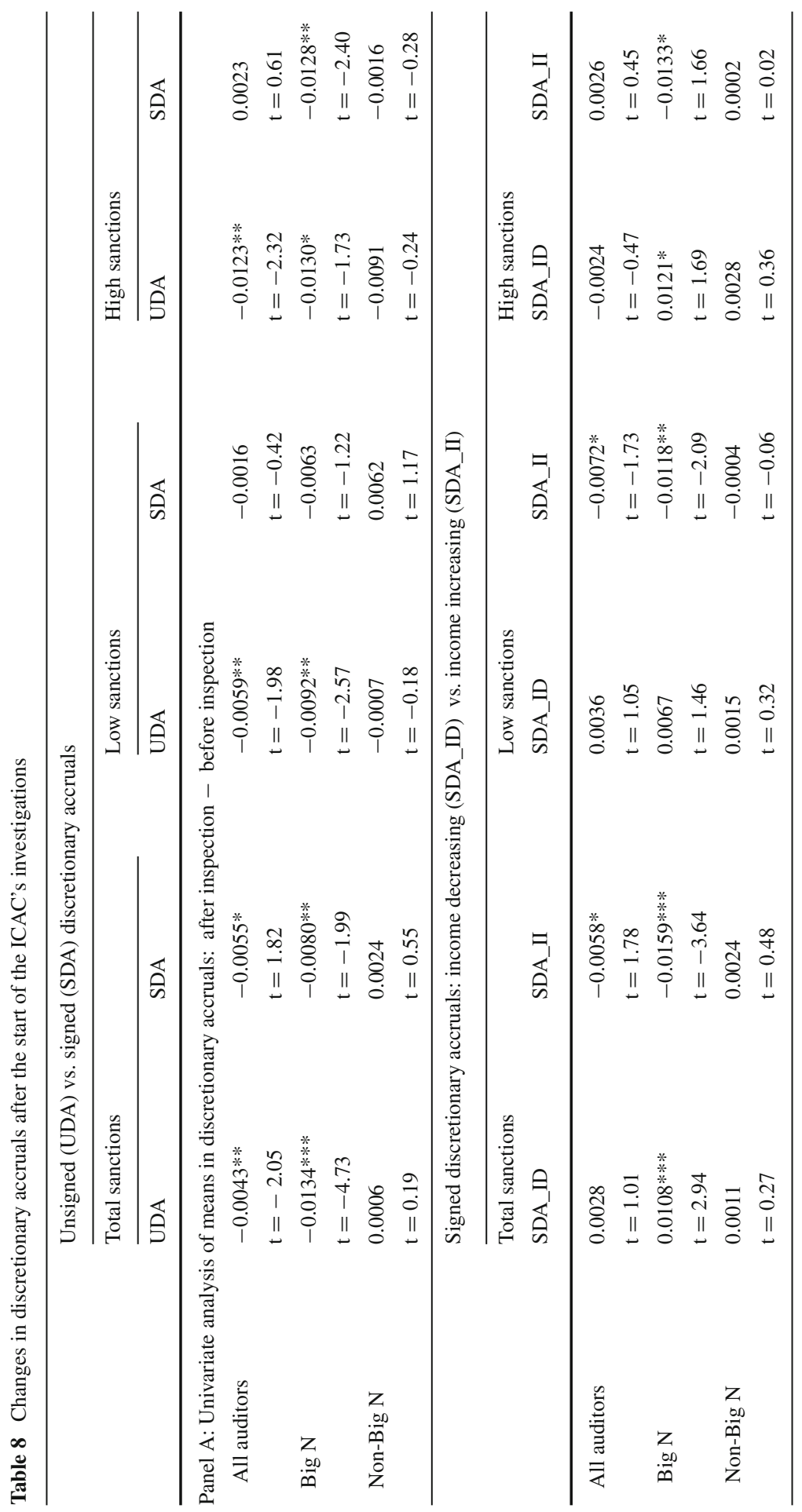




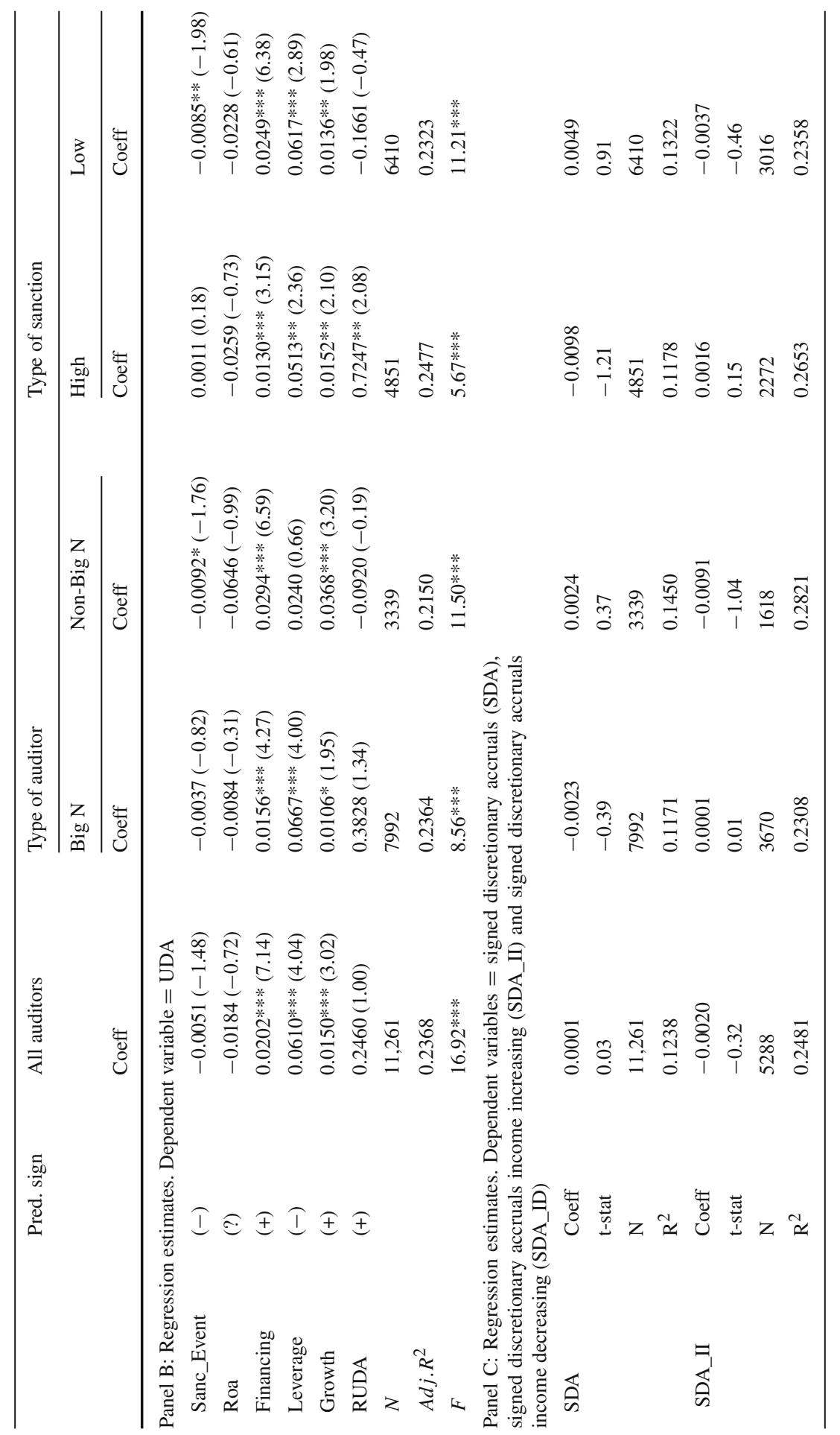




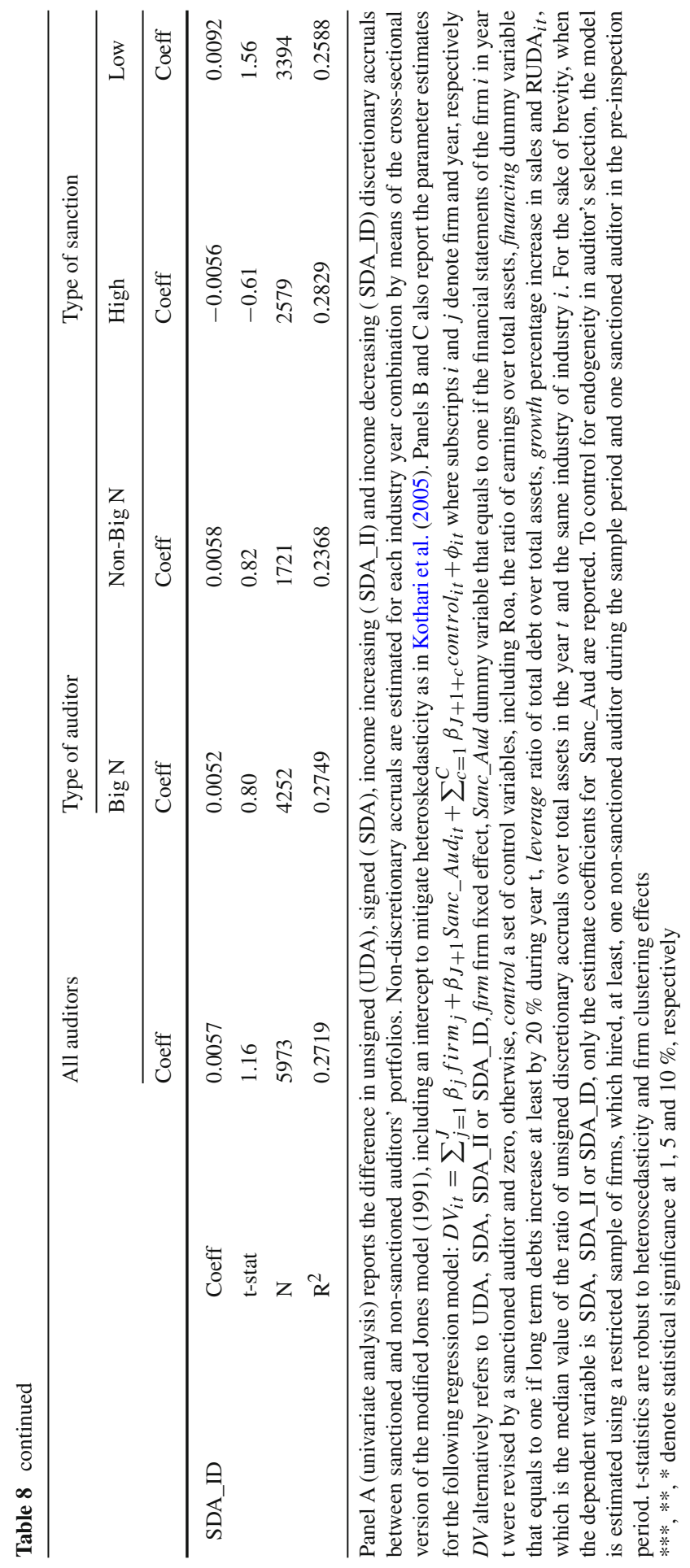


by a larger number of stakeholders. To determine if our results hold for different firm sizes, we empirically test Hypotheses 1 and 2 using two subsamples of firms with total assets below and above 13.75 million $€$. Our tests bring mixed results. When using the likelihood of loss reporting as an indicator of earnings quality, the difference in audit quality between the sanctioned and the non-sanctioned auditors is higher for small firms. When using discretionary accruals, however, the difference in audit quality between the types of auditors increases with the client's company size.

Finally, following the suggestion of one anonymous reviewer, we conducted the abnormal accrual analysis including industry fixed effects, and the results, although not reported, confirm our prior results.

\section{Conclusions}

In the last decade we have witnessed a global move toward increased external oversight of the auditing industry and away from the self-regulatory framework promoted by professional organizations. In the USA, the Sarbanes-Oxley Act empowered the Public Accounting Company Oversight Board with the right to impose sanctions on detected noncompliance with auditing standards. This enforcement mechanism may also be found in Canada and in France and some other European countries.

There is little evidence in the literature, however, on the effects of external investigations and disciplinary sanctions on auditor behavior. In this paper, we analyze disciplinary actions imposed by the ICAC to see if they prompt changes in audit quality. In particular, we use two client-specific earnings-quality measures (i.e., the likelihood of reporting losses through extraordinary items and discretionary accruals), aimed at capturing different dimensions of audit quality.

To evaluate the ability of sanctions to signal low average audit quality, we computed our two audit quality measures in a subsample of client companies that hired at least one sanctioned auditor in the pre-inspection period and one non-sanctioned auditor in any year of the sample period, 1995-2007. Our results confirm that clients of Non-Big 4 sanctioned auditors exhibit lower average earnings quality, specifically, the avoidance of reporting bottom-line losses. The evidence from the discretionary accruals approach, however, is not conclusive.

Contrary to our expectations, the results are significant only when the auditors were penalized with lower sanctions. Once more, the evidence from analysis of earnings management through discretionary accruals is not conclusive.

Among the limitations of our work, it is noteworthy that we have grouped fines above $€ 6000$ and nonmonetary sanctions in a single category, because only five engagement partners were penalized with temporary suspension. But further evidence on the impact of nonmonetary sanctions would help to better design the disciplinary system.

Additional tests were conducted using the year of sanction disclosure as a benchmark, but we failed to find any statistical difference in the earning's management measures used in this study. We concluded, therefore, that auditors' permissive behavior is modified when the inspection process is initiated and is not associated with the date of ICAC's publication. A plausible explanation for this finding may be the excessive length of the investigation process that allows time for auditors and auditing 
firms to make pre-emptive improvements to their auditing behaviors and audit quality outcomes.

We must also introduce a caution: Because we lack information about the audit quality evaluations that fail to find any deficiency, we do not provide any estimation of bad auditors not identified by the ICAC's investigations. Other methodologies to overcome the question related to sample selection, as discussed in Lawrence et al. (2011), could also trigger different conclusions.

Our period of analysis ends in 2007, the year in which the new General Accounting Plan adapted the International Financial Reporting Standards (IFRS) to cover unlisted companies, but further research covering subsequent periods would demonstrate if the effectiveness of the disciplinary system in precipitating changes in auditor behavior has been enhanced or constrained by the major accounting changes triggered by the adaptation of the IFRS system. This study is also limited to the investigations over audit engagements, but additional evidence on the efficacy and effectiveness of the regular inspections that are compelled by the Directive 2006/43/EC would be helpful for the audit industry and policy makers alike.

Acknowledgments An earlier version of this paper was presented at the 3rd Workshop on Audit Quality, 5th EARNET Symposium, the 33rd EAA Annual Conference, and the 7th Workshop on Empirical Research in Financial Accounting. The authors would like to thank J. M. Garcia-Lara, Robert Knechel, Flora Muiño, Juan Monterrey, Anna Samsonova, Jeroen Van Raak, and seminar participants at Universidad de Murcia, Universidad Carlos III, Universitat de Valencia, Universitat de Lleida, Universitat Pompeu-Fabra, the 5th EARNET Symposium, the 33rd EAA Annual Conference and the 7th Workshop on Empirical Research in Financial Accounting for their helpful comments and suggestions. We also thank Jose Antonio Gonzalo Angulo and other ICAC members for their helpful suggestions. Comments from two anonymous reviewers definitely helped to enhance the quality of this paper. This paper has received financial support from the Ministerio de Educación, Cultura y Deportes and the Junta de Andalucía, under projects ECO2011-29144C03-02 and SEJ-8236, respectively.

Open Access This article is distributed under the terms of the Creative Commons Attribution 4.0 International License (http://creativecommons.org/licenses/by/4.0/), which permits unrestricted use, distribution, and reproduction in any medium, provided you give appropriate credit to the original author(s) and the source, provide a link to the Creative Commons license, and indicate if changes were made.

\section{References}

Aguiar-Díaz I, Díaz-Díaz N (2015) Audit quality, second-tier and size: effect on the Spanish private distressed firms. Rev Esp Financ Contab 44(1):24-46

Ali A, Chen T-Y, Radhakrishnan S (2007) Corporate disclosures by family firms. J Account Econ 44:238286

Ahmed A, Billings B, Morton R, Stanford-Harris M (2002) The role of accounting conservatism in mitigating bondholder-shareholder conflicts over dividend policy and in reducing debt costs. Account Rev $77: 867-890$

Anantharaman D (2012) Comparing self-regulation and statutory regulation: evidence from the accounting profession. Account Organ Soc 37:55-77

Arnedo Ajona L, Lizarraga Dallo F, Sánchez Alegría S (2008) Discretionary accruals and auditor behavior in code-law contexts: an application to failing Spanish firms. Eur Account Rev 17(4):641-666

Baber WR, Kumar KR, Verghese T (1995) Clients security price reactions to the Laventhol and Horwath bankruptcy. J Account Res 33(2):385-395

Baker CR, Bèdard J, Prat dit Hauret C (2014) The regulation of statutory auditing: an institutional theory approach. Manag Audit J 29(5):371-394 
Ball R, Shivakumar L (2005) Earnings quality in UK private firms: comparative loss recognition timeliness. J Account Econ 39:83-128

Beatty AL, Ke B, Petroni KR (2002) Earnings management to avoid earnings declines across publicly and privately held banks. Account Rev 77(3):547-570

Becker C, DeFond M, Jiambalvo J, Subramanyam KR (1998) The effect of audit quality on earnings management. Contemp Account Res (Spring): 1-24

BOICACs (Boletín del Instituto de Contabilidad y Auditoría de Cuentas), Bulletins from 1995 until 2008. In: Ministerio de Economía y Hacienda (ed) Ministerio de Economía y Hacienda, Madrid

Burgstahler DC, Hail L, Leuz C (2006) The importance of reporting incentives: earnings management in European private and public firms. Account Rev 81(5):983-1016

Cano M (2007) Tamaño del auditor y calidad de la auditoría en las empresas españolas no cotizadas. Rev Esp Financ Contab 36(135):481-508

Cano M (2010) Big auditors, private firms and accounting conservatism: Spanish evidence. Eur Account Rev 19(1):131-159

Carcello J, Hollingsworht C, Mastrolia S (2011) The effect of PCAOB inspections on Big 4 audit quality. Res Account Regulat 23:85-96

Carmona P, Momparler A (2011) La prestación de servicios de consultoría por los auditores y la manipulación del resultado: estudio de la independencia del auditor en un país de la UE. Rev Esp Financ Contab 60(152):587-612

Casterella JR, Jensen KL, Knechel WR (2009) Is self-regulated peer review effective at signaling audit quality? Account Rev 84(3):713-735

Corten M, Steijvers T, Lybaert N (2015) The demand for auditor services in wholly family-owned private firms: the moderating role of generation. Account Bus Res 45(1):1-26

Chaney PK, Philipich KL (2002) Shredded reputation: the cost of audit failure. J Account Res 40(4):12211245

DeFond M (2010) How should the auditors be audited? Comparing the PCAOB inspections with the AICPA peer reviews. J Account Econ 49:104-108

DeFond M, Lennox C (2011) The effect of SOX on small auditor exits and audit quality. J Account Econ 52:21-40

Dechow PM, Dichev ID (2002) The quality of accruals and earnings: the role of accrual estimation errors. Account Rev 77(sup.):35-59

De Fuentes C, Sierra E (2015) Industry specialization and audit fees: a meta-analytic approach. Acad Rev Latinoam Adm 28 (3) (forthcoming)

De Fuentes C, Garcia-Benau MA, Pucheta-Martinez MC, Ruiz-Barbadillo E (2015) El éxito de los procesos de fusión en el mercado de auditoria: El caso de PriceWaterhouseCoopers. Rev Contab Span Account Rev 18(1):55-67

De las Heras E, Cañibano L, Moreira JA (2012) The impact of the Spanish Financial Act (44/2002) on audit quality. Rev Esp Financ Contab 41(156):521-546

Directive 2006/43/EC of the European Parliament and of the Council of 17 May 2006 on statutory audits of annual accounts and consolidated accounts, amending Council Directives 78/660/EEC and 83/349/EEEC and repealing Council Directive 84/253/EEC

Ferguson A, Francis J, Stokes D (2003) The effects of firm-wide and office-level industry expertise on audit pricing. Account Rev 429-448

Fogarty TJ (1996) The imagery and reality of peer review in the US: insigths form instituional theory. Account Organ Soc 21:243-267

Francis J, Reichelt K, Wang D (2005) The pricing of national and city-specific reputations for industry expertise in the US audit market. Account Rev 80(1):113-136

Francis J, Maydex E, Sparks H (1999) The role of Big 6 auditors in the credible reporting of accruals. Audit J Pract Theory 18(2): 17-34

Gallén L, Giner B (2005) La alteración del resultado para evitar pérdidas y descensos: evidencia empírica. Rev Esp Financ Contab 34(124):141-181

García-Osma B, Gisbert A, De las Heras-Cristobal E (2014) Public oversight systems for statutory auditors in the European Union. Eur J Law Econ 38. doi:10.1007/s10657-014-9460-1

Gonzalo Angulo JA (2014) La reforma contable en España de 2007: un balance. Rev Contab Span Account Rev 17(2):183-200

Gramling A, Krishnan J, Zhang Y (2011) Are PCAOB-identified audit deficiencies associated with a change in reporting decisions of triennially inspected audit firms? Audit J Pract Theory 30(3):59-79 
Gunny K, Zhang T (2013a) PCAOB inspection reports and audit quality. J Account Public Policy 32:136160

Gunny K, Zhang T (2013b) When the PCAOB talks who listens? Evidence from stakeholder reactions to GAAP-Deficient PCAOB inspection reports of small auditors, Auditing: A Journal of Practice and Theory 32(2): 1-31

Hilary G, Lennox C (2005) The credibility of self-regulation: evidence from the accounting profession's peer review program. J Account Econ 40:211-229

Hribar P, Nichols C (2007) The use of unsigned earnings quality measures in tests of earnings management. J Account Res 45(5):1017-1053

Huguet D, Gandía JL (2014) Cost of debt capital and audit in Spanish SMEs. Rev Esp Financ Contab 43(3):266-289

Jones JJ (1991) Earnings management during import relief investigations. J Account Res 29(2):193-228

Kothari SP, Leone AJ, Wasley C (2005) Performance match discretionary accruals measures. J Account Econ 39(1): 163-197

Krishnan G (2003) Audit quality and the pricing of discretionary accruals. Audit J Pract Theory 22(1):109126

La Porta R, Lopez-de-Silanes F, Shelifer A (1998) Law and finance. J Polit Econ 106(6):1113-1155

Lawrence A, Minutti-Meza M, Zhang P (2011) Can Big 4 versus Non-Big4 differences in audit-quality proxies be attributed to client characteristics? Account Rev 86(1):259-286

Lennox C, Pittman J (2010) Auditing the auditors: evidence of the recent reforms to the external monitoring of audit firms. J Account Econ 49(Feb):84-103

Leuz Ch, Nanda D, Wysocki PD (2003) Earnings management and investor protection: an international comparison. J Financ Econ 69(3):505-527

Menon K, Williams JD (1994) The use of audit committees for monitoring. J Account Public Policy 13:121139

Monterrey MJ, Sánchez-Segura A (2006) Las características socioeconómicas como incentivos para la información financiera: evidencia empírica española". Investig Econ 30(3):611-634

Public Overisght Board (2002) The road to reform: a white paper from the public oversight board on legislation to create a new private sector regulatory structure for the accounting profession. POB, Stamford, p 19

Real Decreto (1636/1990) de 20 de diciembre, por el que se aprueba el Reglamento que desarrolla la Ley 19/1988, de 12 de Julio, de auditoría de cuentas

Serrano Madrid J, Ruiz Barbadillo E, Martinez Conesa I (2012) Análisis empírico de la prima por riesgo de negocio en el mercado de auditoría de pequeñas y medianas firmas auditoras en España. Rev Esp Financ Contab 62(158):239-270

Van de Ven W, Van Pragg B (1981) The demand for deductibles in private health insurance: a probit model with sample selection. J Econ 17:229-252

Van Tendeloo BA, Vanstraelen A (2008) Earnings management and audit quality in Europe: evidence from private client segment market. Eur Account Rev 17(3):447-469

Wang D (2006) Founding family ownership and earnings quality. J Account Res 44(3):619-656

Wilson TE Jr, Grimlund RA (1990) An examination of the importance of an auditor's reputation. Audit J Pract Theory 9(2):43-59 